James E. Harris

Joseph Greenberg

U.S. DEPARTMENT OF COMMERCE

National Bureau of Standards

National Engineering Laboratory

Center for Building Technology

Building Environment Division

Gaithersburg, MD 20899

May 1987

Final Report

Prepared for:

Building Equipment Division

ice of Buildings and Community Systems

OC i. Department of Energy

100 shington, DC 20585

U56

$1.87-3537$

187 



\section{PERFORMANCE OF INSTANTANEOUS GAS-FIRED WATER HEATERS}

James E. Harris

Joseph Greenberg

U.S. DEPARTMENT OF COMMERCE

National Bureau of Standards

National Engineering Laboratory

Center for Building Technology

Building Environment Division

Gaithersburg, MD 20899

May 1987

Final Report

\section{Prepared for:}

Building Equipment Division

Office of Buildings and Community Systems

U.S. Department of Energy

Washington, DC 20585

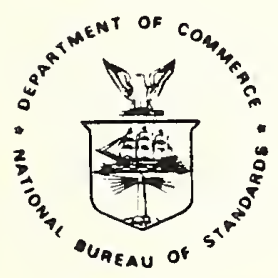

U.S. DEPARTMENT OF COMMERCE, Malcolm Baldrige, Secretary NATIONAL BUREAU OF STANDARDS, Ernest Ambler, Director 

Four different instantaneous, gas-fired water heaters were tested to develop a test method to determine recovery efficiency (Er) and energy factor (EF). All four of the water heaters were from foreign countries (West Germany, the United Kingdom, France and Japan). Various flow rates and water draws were used during the tests to determine their influence on the recovery efficiency and energy factor. In addition, the pilot light power consumption was measured to determine the effect of a variable pilot light power rate on the energy factor. The use of recovery efficiency as a performance index seems appropriate for these units, however, the use of energy factor, as presently calculated, needs further study. 


\section{DISCLAIMER}

This report is intended to provide the baseline for the development of test procedures for instantaneous water heaters and not to judge the performance of the water heaters for any specific application. Although the units tested were not identified by manufacturer, inclusion of a given unit in this report in no case implies a recommendation or endorsement by the National Bureau of Standards, and the presentation should not be construed as a certification that any unit would provide the indicated performance. Similarly, the omission of a unit does not imply that its capabilities are more or less than those of the included units. 


\section{ACKNOWLEDGEMENTS}

The authors wish to acknowledge the contribution of Douglas L. Hawk, Mechanical Engineering Student at the University of Maryland, for efficiently and professionally conducting the tests described herein and to Dianna Mills for her efforts in typing this document for publication. 


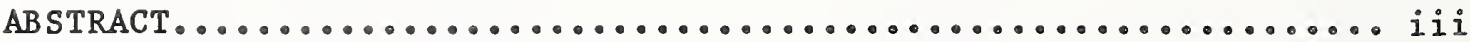

DISCLAIMER. ......................................

ACKNOWLEDGEMENTS .................................. v

LIST OF TABLES..................................... viii

LIST OF FIGURES ................................... ix

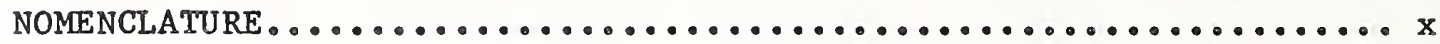

1. INTRODUCTION................................. 1

1.1 objective............................... 1

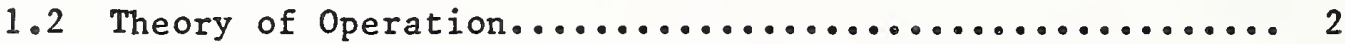

1.3 Potential Applications......................... 3

2. SCOPE AND TEST PROCEDURES........................ 4

2.1 scope..................................... 4

2.2 Test Set-up and Laboratory Conditions............... 5

2.3 Measurements Taken........................... 7

2.4 Test Procedures.............................. 7

3. TEST DATA................................... 9

4. TEST RESULTS AND CALCULATIONS....................... 10

4.1 Water Flow Rate Versus Temperature Rise.............. 10

4.2 Calculation of Recovery Efficiency................. 13

4.3 Portable Combustion Efficiency Analyzer Results........ 14

4.4 Calculation of Energy Factor...................... 14

5. DISCUSSION................................. 17

5.1 Determination of Unit GPM at a

Temperature Rise of $77^{\circ} \mathrm{F} \ldots \ldots \ldots \ldots \ldots \ldots \ldots \ldots . \ldots \ldots 17$

5.2 Determination of Recovery Efficiency................ 19

5.3 Determination of Energy Factor.................... 20

6. CONCLUSIONS .................................. 21

7. REFERENCES................................... 22

APPENDIX A - COMPUTATIONS AND FORMULAS USED................. A-1

1.0 Gas Correction Factor.........................A-1

2.0 Energy Used During a Test...................... A-2

3.0 Mean Outlet Hot Water Temperature................A-2

4.0 Mean Water Supply Temperature....................A

5.0 Recovery Efficiency............................ A-3

6.0 Daily Water Heating Energy Consumption.............. A-4

7.0 The Flow Rate During a Draw..................... A-4 
8.0 Power (Firing Rate) Determination................A

9.0 Daily Hot Water Energy Consumption................ A-5

10.0 Pilot Light Energy Consumption Rate..............A A-5

11.0 Average Daily Energy Consumption................. A-6

12.0 Energy Factor.............................A

APPENDIX B - UNITS CONVERSION TABLE: SI/INCH-POUND/SI_.......B-I 
Table 1a Test Data - Unit F........................... 24

Table 1b Test Data $=$ Unit G......................... 25

Table Ic Test Data - Unit H............................ 26

Table Id Test Data - Unit I......................... 27

Table 2 a Summary Data, Er, and EF - Unit F............... 28

Table $2 b$ Summary Data, Er, and EF - Unit G................ 29

Table 2c Summary Data, Er, and EF - Unit H............... 30

Table 2d Summary Data, Er, and EF - Unit I................ 31 
Page

Figure 1. Instantaneous Gas-Fired Water

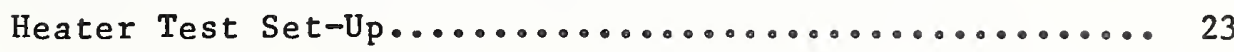

Figure 2. Temperature Rise vs. Flow Rate - Unit F........... 32

Figure 3. Temperature Rise vs. Flow Rate - Unit G........... 33

Figure 4. Temperature Rise vs. Flow Rate - Unit H........... 34

Figure 5. Temperature Rise vs. Flow Rate - Unit I........... 35

Figure 6. Recovery Efficiency (Er) and

Energy Factor (EF) vs. Flow Rate - Unit F.......... 36

Figure 7. Recovery Efficiency (Er) and

Energy Factor (EF) vs. Flow Rate - Unit G.......... 37

Figure 8. Recovery Efficiency (Er) and

Energy Factor (EF) vs. Flow Rate - Unit H........... 38

Figure 9. Recovery Efficiency (Er) and

Energy Factor (EF) vs. Flow Rate - Unit I.......... 39 


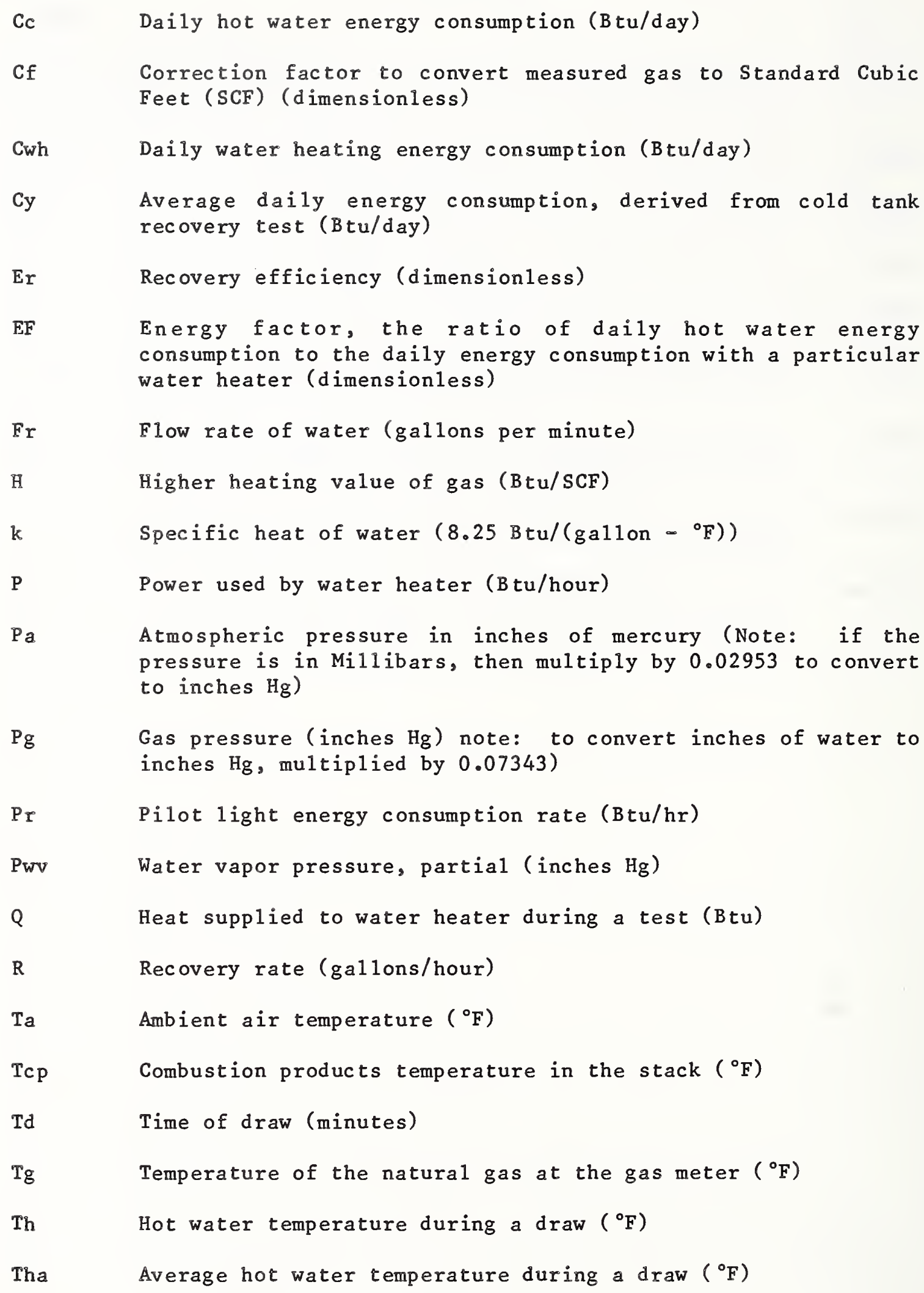


Ti Inlet (supply) water temperature $\left({ }^{\circ} \mathrm{F}\right)$

Tia Average inlet (supply) water temperature $\left({ }^{\circ} \mathrm{F}\right)$

U The nominal daily hot water usage

Vo1 The measured volume of gas used during a test (cubic feet)

Ww Weight of water drawn (pounds) 



\section{INTRODUCTION}

Four different instantaneous, gas-fired water heaters were tested to develop a test method to determine the recovery efficiency, Er, and energy factor, EF, for these units. Although thermal efficiency and standby loss tests have been defined by the American Gas Association and published as ANSI Standards $[1,2] *$, the tests were not prepared in the contex of an integrated, overall energy conservation program for water heaters. These water heater types have been called by a number of other descriptive names: i.e. in-line, tankless, demand, point of use, geyser and instantaneous. In this report, the designation "instantaneous" will be used. These water heaters are of interest for their potential to save energy since they should have lower standby losses, perhaps higher recovery efficiencies and energy factors than storage type gas-fired water heaters currently in use.

\section{1 objective}

The objectives of these tests were: (1) to establish a baseline for the development of an appropriate test method for instantaneous water heaters; (2) to characterize the performance of instantaneous, gasfired water heaters; (3) to use the test data to determine a method of calculating a recovery efficiency, Er, and energy factor, EF, for instantaneous water heaters; (4) to judge the adequacy of using these

* Note: Numbers in brackets refer to references at the end of the report. 
factors to rate instantaneous water heaters and; (5) to assess the suitability of these factors in comparing the performance of instantaneous water heaters to storage type water heaters.

\subsection{Theory of Operation}

Instantaneous water heaters provide hot water on demand. Because these are tankless heaters, they avoid some of the standby losses, namely flue and jacket losses, usually associated with storage type units. Most of the currently produced units have integral controls to modulate the firing rate of the main burner as a function of water flow rate or outlet water temperature although some of the older units have fixed firing rate burners. In addition, most units have some minimum flow to activate (turn-on) the main burner. The main burner also is provided with the usual proof-of-flame sensor device along with high temperature and other safety features required for automatic, gas-fired appliances.

Units which incorporate flow sensor devices are activated by variable water flow rates to modulate the gas flow rate to the main burner. These units generally have a knob on the control panel to provide a convenient means to manually set the regulated temperature rise of the hot water. Turning this knob adjusts the flow sensor control mechanism which controls main burner modulation. Other heaters use a thermal sensing bulb filled with an expandable fluid that expands and contracts in response to the temperature changes of the water in the finned-tube heat exchanger. The expanding fluid actuates a bellows that increases the opening of the main burner gas control valve to modulate the burner firing rate to control the hot water temperature within a certain 
range. This second type is a thermostatically modulated control whereas the first type is a flow modulated control.

As the flow rate of the hot water is increased, the firing rate of the main burner is increased to maintain the hot water discharge temperature at or near the particular temperature set point. Further increases in flow rates of the hot water beyond that corresponding to the maximum firing rate will result in a corresponding decrease in the hot water temperature as the flow rate is above the range of modulation. In all types of instantaneous gas-fired water heaters, a cessation of hot water flow extinguishes the main burner.

All of the units have pilot lights which are started by manually operating a push button to activate a piezoelectric spark igniter. The pilot light remains activated enabling it to ignite the main burner as often as required to satisfy any subsequent hot water draws. Pilot lights may be manually extinguished to save energy if hot water usage is not anticipated for an extended time.

\subsection{Potential Applications}

In domestic household applications, instantaneous water heaters may be installed :

(1) In a central location, as a replacement for a storage type water heater in typical use in the U.S. In this application, some standby losses may be reduced since there is no stored hot water and no associated jacket losses. 
(2) In series with a separately fired hot water storage tank, where the hot water is stored in the tank at a reduced temperature. When hot water is drawn, the instantaneous water heater serves as a booster heater to increase the water temperature to some higher value. Energy may be saved from reduced standby losses of the storage tank because of the lower temperature of the stored water.

(3) Locally at selected hot water usage points where each instantaneous water heater operates independently. In addition to the reduction of the standby losses by the elimination of jacket and flue losses, there may be reduced piping heat losses since pipe runs to the point of use would generally be shorter.

(4) In conjunction with an insulated storage tank with a circulating pump and suitable controls allowing the system to function as a indirect-fired storage type water heater. In this configuration, flue losses may be reduced as a contributor to the standby losses and it is possible that the recovery efficiency may be higher than that of conventional gas-fired storage water heaters because of the use of finned tube heat exchangers. Also, instantaneous water heaters with reduced firing rates might be used if the hot water were stored in an insulated storage tank. Some efficiencies gained may be offset, however, because of the required water circulating pump and controls.

2. SCOPE AND TEST PROCEDURES

\subsection{Scope}

Four (4) instantaneous natural gas-fired water heaters were tested. They all vary in water heating capability and all are manufactured 
overseas namely: West Germany, Great Britain, France, and Japan. It should be emphasized that the testing conducted on these units were not meant to evaluate the units themselves but rather to aid in the development of meaningful test procedures on a generic basis for all instantaneous type water heaters.

\subsection{Test Setup and Laboratory Conditions}

The test setup for instantaneous gas-fired water heater testing is shown in Figure 1. Units were designated F, G, H, and I (1etters A through $\mathrm{E}$ were used for tests of other types of water heaters not reported herein) and each unit tested separately through the manual setting or control of the appropriate gas and water valves. The testing setup also allowed the required instrumentation to be used efficiently with a minimum of change or modification.

The supply water temperature was conditioned to the desired temperature (normally $70^{\circ} \mathrm{F}^{\circ} *$ ) in the conditioning tanks and circulated by a pump to ensure that the inlet supply water to the instantaneous heaters was of a uniform temperature during testing. Appropriate valves were set so that the domestic supply water pressure was used to pressurize the water system to force the flow of water as required by the hot water

\footnotetext{
** Note: In this report inch-pound units are generally used to be consistent with DOE and other published test procedures although some temperature data were collected in degrees Celsius. An S/I conversion table is included in Appendix B.
} 
draws. Water flow rates were set by control valves and the flow rate was monitored by a flow meter.

The total volume of water drawn during the test was measured by using a 120 gallon collecting tank mounted on a balance beam scale. The balance beam was fitted with an electrical switch which controlled a valve on the supply water inlet to the instantaneous water heater being tested. After water flow was initiated, the outlet hot water coming from the instantaneous water heater was collected in the 120 gallon tank, the weight of the incoming water gradually leveled the balance beam. When a predetermined weight representing the total water volume to be drawn was reached, the electrical switch on the balance beam was activated. This stopped the supply water flow to the water heater and ended the test. The actual flow rate was calculated by timing and weighing the total water flow.

During certain tests, a portable combustion efficiency analyzer was used to determine combustion efficiency. This measurement was to be compared later to the calculated water heater efficiency for correlation.

Tests were conducted at a laboratory ambient temperature of approximately $70^{\circ} \mathrm{F}$. All water heaters were tested with draw tests since the burner is activated only by a draw. A traditional recovery test [3] which draws no water was not a suitable type of test for an instantaneous type water heater. Although this type of water heater 
has no storage tank, a recovery efficiency was calculated for each test (see Section 4, Test Results and Calculations). The pilot light gas consumption rate was measured for all water heaters tested.

\subsection{Measurements Taken}

The following measurements were taken and recorded for each test.

1. Ambient air temperature, Ta

2. Natural gas inlet temperature, $\mathrm{Tg}$

3. Inlet (supply) water temperature, $\mathrm{Ti}$

4. Outlet (hot) water temperature, Th

5. Stack (combustion products) temperature, Tcp

6. Amount of hot water drawn during a test (in pounds), Ww

7. Time of draw (in minutes, used to accurately measure flow rate), Td

8. Barometric air pressure (in milli-bars and converted to inches of mercury), $\mathrm{Pa}$

9. Higher heating value of natural gas and converted to Btu per SCF, $\mathrm{H}$

10. Inlet (supply) natural gas pressure measured in inches of water column and converted to inches of mercury, $\mathrm{Pg}$

11. Quantity of natural gas used in cubic feet and converted to standard cubic feet, Vol.

\subsection{Test Procedures}

In general, the following procedures were followed for the testing of each instantaneous gas-fired water heater: 
1. Water in the conditioning tanks was prepared for use as the inlet (supply) water for the instantaneous heater test by heating or cooling, as needed, to bring the supply water to the desired starting temperature。

2. The drain valve on the 120 gallon water collecting tank was opened to ensure that the tank was empty. The valve was then closed and the balance beam was set to activate the switch so as to stop the flow of supply water after the required weight of hot water was collected from the instantaneous water heater being tested.

3. Water control valves were set to provide domestic water line pressure to the supply tanks.

4. The water heater to be tested was isolated by turning off the cold water supply valves to all other water heaters. The appropriate gas valves were set to assure that only the water heater to be tested had natural gas supplied, then, the pilot light was ignited by following the specific instructions for the particular water heater.

5. The datalogger was set to record the necessary thermocouple measurements (input supply water temperature, outlet hot water temperature, and ambient air temperature) at one minute intervals.

6. The natural gas meter and the barometric pressure were read.

7. The test was initiated by opening the water inlet valve to the instantaneous water heater using the flow meter to set the nominal test flow rate. Simultaneously, the datalogger and timer were started.

8. While a draw was being made and the water heater burner was activated, the natural gas pressure and the portable combustion 
efficiency analyzer were read. The portable combustion efficiency analyzer which measures combustion products and temperatures was used only for a selected number of tests.

9. When the draw was complete the scale beam tipped to cause the cold water supply control valve to close and terminate the water flow. The elapsed time since the start of the draw was recorded as well as the natural gas meter reading.

10. The tank drain valve was then opened to empty the 120 gallon collecting tank, and the datalogger reset to prepare for the next test.

\section{TEST DATA}

A number of tests were conducted on each of the four instantaneous water heaters. The test data are shown in Tables $1 \mathrm{a}, 1 \mathrm{~b}, 1 \mathrm{c}$, and $1 \mathrm{~d}$ for Units F, G, H, and I, respectively. Each tested unit is shown along with an identifying test number and each test series is identified by sequential test numbers. The higher heating value of the gas, $H$, is the same for all the tests conducted within the series.

As can be observed, the hot water flow rates were varied from approximately 1 gallon per minute (GPM) to approximately 3 GPM although several tests were conducted at a hot water flow rate of approximately 4 GPM for Unit H. For each test, the total amount of hot water drawn is also indicated, varying from 5 gallons to 50 gallons. Most tests, however, were conducted using a total volume of 21.4 gallons which corresponds to the first draw volume of the proposed simulated use test for storage type water heaters [4]. The simulated use test for storage 
type water heaters is conducted by drawing a total of 64.3 gallons in three equal draws of 21.4 gallons each.

The measured inlet and outlet temperature, in degrees Celsius, is also shown in Tables la through ld along with the correction factor, Cf, used to convert measured gas to "standard" cubic feet, SCF; the cubic feet of gas used during the test, CuFt; and the higher heating value for the gas used, H. The measured pilot light energy consumption for each unit is also indicated along with the corresponding hourly BTU rate.

For convenience, the inlet and outlet water temperatures as well as the outlet minus inlet water temperature, $\mathrm{T} 1$, are a1so shown in degrees Fahrenheit. Finally, the Btu content of the gas, Q, used for each test is calculated as the product of $(\mathrm{C} f)(\mathrm{Vol})(\mathrm{H})$ and indicated in Tables la through $1 \mathrm{~d}$.

\section{TEST RESULTS AND CALCULATIONS}

\subsection{Water Flow Rate Versus Temperature Rise}

In order to characterize each of the tested units regarding its ability to provide hot water, the data shown indicating flow rate, GPM, and temperature rise, Tl, from Tables la through ld were plotted. The results for Units F, G, H and $I$ are shown in Figures 2, 3, 4, and 5, respectively. For each graph, the results for the 21.4 total draw test series are generally connected by lines for clarity. In addition, the total gallons of water drawn for each test is indicated. 
For Unit F, the draw rates varied from approximately one to three GPM as shown in Figure 2. As can be seen, the congruency of the GPM versus Temperature Rise lines are rather scattered and some of the data points at draw rates of approximately 1 GPM, for a total draw of 5 and 10 gallons, are somewhat anomalous. The predominant GPM versus Temperature Rise trend is approximately linear from about a temperature rise of $68^{\circ} \mathrm{F}$ at $1 \mathrm{GPM}$ to $45^{\circ} \mathrm{F}$ at $3 \mathrm{GPM}$ as represented by two of the draws from the 21.4 gallon series tests and the 15 gallon draw tests. The third 21.4 gallon series plot is offset from the others. Note that Unit $\mathrm{F}$ cannot provide hot water at a temperature rise of $77^{\circ} \mathrm{F}$ which represents water heated from an inlet temperature of $58^{\circ} \mathrm{F}$ to an outlet temperature of $135^{\circ} \mathrm{F}$. It does, however, provide hot water above a temperature rise of $55^{\circ} \mathrm{F}$ at $2 \mathrm{GPM}$. This temperature rise represents hot water at $113^{\circ} \mathrm{F}$ if the inlet water is $58^{\circ} \mathrm{F}$; which is a water temperature considered useful for most domestic hot water uses.

The GPM versus Temperature Rise characterization for Unit G is shown in Figure 3. In this case, the GPM versus Temperature Rise lines are fairly congruent and linear from a temperature rise of approximately $85^{\circ} \mathrm{F}$ at $1.7 \mathrm{GPM}$ to a temperature rise of $47^{\circ} \mathrm{F}$ at $3.2 \mathrm{GPM}$. These 1 ines represent hot water draws of 5 gallons, 21.4 gallons, and 50 gallons. As can be seen, Unit $G$ is capable of producing hot water at a temperature rise of $77^{\circ} \mathrm{F}$, again, representing the heating of water from an inlet temperature of $58^{\circ} \mathrm{F}$ to an outlet temperature of $135^{\circ} \mathrm{F}$ at a flow rate of approximately 1.9 GPM. For Unit G, the range from I GPM and 1.7 GPM represents main burner modulation range at these lower flow 
rates. These points are rather scattered and tend toward a higher temperature rise with an increase in flow rate, as might be expected within this flow rate range.

Unit $H$ exhibits the trend in GPM versus Temperature Rise characteristics as shown in Figure 4. From a temperature rise of approximately $86^{\circ} \mathrm{F}$ at $1 \mathrm{GPM}$ to a temperature rise of approximately $45^{\circ} \mathrm{F}$ at 4 GPM, the trend appears somewhat uniform with the exception of the 7.5 gallon data points. In addition, the lines exhibit little similarity within the overall range. This unit will deliver hot water at a temperature rise of $77^{\circ} \mathrm{F}$ with a flow rate of approximately 1.7 GPM。

Unit I, the unit with the highest firing rate in $B t u / h r$ input of the four units tested also exhibited a somewhat linear characteristic with reasonable similarities from a temperature rise of approximately $89^{\circ} \mathrm{F}$ at 2.2 GPM to a temperature rise of approximately $69^{\circ} \mathrm{F}$ at $3 \mathrm{GPM}$, if the single $81^{\circ} \mathrm{F}$ temperature rise at 3 GPM data point is not included (see Figure 5). Data points at flow rates less than approximately 2.2 GPM represent the unit operating within the range of modulation. This unit provides the highest flow hot water rate of approximately 2.6 GPM at a temperature rise of $77^{\circ} \mathrm{F}$ of the four units tested. It should be noted that Unit I was not operated at its maximum output due to gas line supply restrictions. 


\subsection{Calculation of Recovery Efficiency}

Using the test data shown in Tables la through $1 \mathrm{~d}$ a Recovery Efficiency, Er, was calculated for each test using the equations in Appendix A. These calculated Er's are shown in Tables 2 a through 2d along with the individual values used for the calculation. It should be noted that the Er calculation is based on the active operation of the instantaneous water heater for the actual water volume heated and the actual temperature rise achieved during the test. The water volume is not normalized to any particular volume and the fuel consumed by the pilot light is ignored during the water heater's quiescent period (the time in which the pilot alone is burning and no water is being drawn). The Er for the four units tested varied from approximately 0.72 to 0.90 .

The Er for each unit tested was plotted as a function of water flow rate and is shown in Figures $6,7,8$, and 9, for Units F, G, H, and I, respectively. As can be seen, the lines connecting the points which represent each test series are not congruent. However, the aggregate of the points plotted indicate a general trend showing a higher Er with increased flow rate with an increase in Er ranging from approximately 0.05 to 0.1 between the draw rates of 1 GPM and 3 GPM. The Er for Units F, G, and $\mathrm{H}$ all seem to lie nominally between 0.75 and 0.85 while Unit I shows a nominal Er range from 0.80 to 0.90 .

Generally, the Er appears to be somewhat sensitive to the flow rate and the temperature rise used for the calculation, as represented by the 
differences of the plotted lines and the small increase in Er at the higher flow rates.

\subsection{Portable Combustion Efficiency Analyzer Results}

A portable combustion efficiency analyzer was used during several tests conducted on Unit $\mathrm{H}$ in order to determine if there was any correlation between the calculated Er and the combustion efficiency. The combustion efficiency analyzer measures the flue gases and analyzes the combustion products and temperatures. A comparison of the combustion efficiencies displayed by the analyzer and the calculated Er for tests 22 through 28 for Unit $H$ is as follows:

\begin{tabular}{|c|c|c|}
\hline & Combustion & Calculated \\
\hline Test & Efficiency & Recovery Efficiency (Er) \\
\hline H22 & .779 & .783 \\
\hline $\mathrm{H} 23$ & .775 & .797 \\
\hline H24 & .754 & .739 \\
\hline H25 & .766 & .766 \\
\hline H26 & $.794 / .787$ & .798 \\
\hline H27 & $.789 / .780$ & .786 \\
\hline H2 8 & $.791 / .787$ & .801 \\
\hline
\end{tabular}

The two combustion efficiency values for tests $26 \mathrm{H}, 27 \mathrm{H}$, and $28 \mathrm{H}$ are given because the analyzer showed two different readings during course of the tests; the second readings were taken about 30 seconds after the first readings. The analyzer updated its reading once each second. As can be noted, the values for the two methods used to determine Er compare rather closely.

\subsection{Calculation of Energy Factor}

Energy Factors, EF, were also calculated for each test using the equations in Appendix A. The calculated EF's are shown in Tables 2a through 2d. The EF is based on a 24 hour simulated use test and 
assumes that a total number of gallons of heated water is drawn at a specified flow rate. It further assumes that during the 24 hour simulated use test, the pilot light of the instantaneous water heater is burning while no water is drawn. The EF is calculated as the ratio of the energy content of a day's supply of hot water divided by the total energy required to provide the hot water plus the energy used by the pilot light during the time hot water is not being drawn.

The EF's calculated for each test for an assumed number of different daily water usages are shown in Tables $2 \mathrm{a}$ through $2 \mathrm{~d}$. The energy consumption of the pilot light for each unit is also shown. It should be noted that these calculations are determined from the actual test data to reflect the EF for the total daily water usages of 20,40 , 64.3 , and 80 gallons.

The EF's for each test as a function of water flow rate for Units F, G, $H$, and $I$ are shown in Figures $6,7,8$, and 9 respectively, along with the plots for Er versus Flow Rate shown in these figures. For clarity, data for a total flow (U) of 64.3 gallons are not shown since the curves would tend to overlap with the data shown for total water drawn for 40 and 80 gallons. The 64.3 gallon data, however, if plotted would fall between the 40 and 80 gallon plots and have the same general shape as the 40 and 80 gallon plots.

All of the EF curves for each of the units tested generally follow the same trends. As can be observed, the greater the total amount of water drawn, the higher the EF. This follows from the fact that the EF is 
calculated over a 24 hour period and the larger the hot water draw the shorter the standby time. It is the energy consumed during this standby time that has a very measurable effect on the EF. As the standby time is decreased by a longer water draw, the EF approaches the Er. The limiting case is when water is drawn continuously for a 24 hour period and there is no standby time when only the pilot light is burning.

It should also be noted that generally the higher the flow rate for a given total draw, the lower is the resulting EF. This is related to the standby time of the instantaneous water heater. If the amount of water to be drawn is removed at a greater flow rate, the recovery time is shortened increasing the standby time and lowering the EF, assuming a constant burning pilot during the standby period.

The Energy Factor is also a function of the pilot light energy consumption rate. The pilot light energy consumption rates for the various units are as follows:

$\begin{array}{ll}\text { Unit F } & 340 \mathrm{Btu} / \mathrm{hr} \\ \text { Unit G } & 357 \mathrm{Btu} / \mathrm{hr} \\ \text { Unit H } & 643 \mathrm{Btu} / \mathrm{hr} \\ \text { Unit I } & 896 \mathrm{Btu} / \mathrm{hr}\end{array}$

Generally, the higher the pilot light energy consumption rate, the lower the EF for a given Er. For example, the Units with the smallest pilot light energy consumption rates (Units $F$ and $G$ ) have Energy Factors of approximately 0.42 for a total hot water draw of 20 gallons at 3 GPM. For the same conditions, Unit $H$ with a pilot light consumption rate of $643 \mathrm{Btu} / \mathrm{hr}$ has an EF of approximately 0.35 and 
Unit I, with a pilot 1 ight consumption rate of $896 \mathrm{Btu} / \mathrm{hr}$ has an EF of approximately 0.32 .

Finally, it should be noted that the EF's shown in Figure $6,7,8$, and 9 vary in congruency and are sensitive to varying degrees to the parameters which are used for the EF calculations. Also, the EF's that show a positive slope derive this slope by following the positive modulating range slope shown for the GPM versus Temperature Rise plots for each Unit.

\section{DISCUSSION}

\subsection{Determination of Unit GPM at a Temperature Rise of $77^{\circ} \mathrm{F}$}

In viewing the graphs of Er and EF with their multiple points as shown in Figures $6,7,8$, and 9 , one might question which of these points represents the Er and EF for the four instantaneous water heaters tested. Since the basis for these factors originate from the points found on the GPM versus Temperature Rise curves shown in Figures 2, 3, 4, and 5, a method for selecting a single point is desirable.

For consistency of comparison, it is advantageous to conduct all water heater tests under the same test conditions. Toward that end, the units should be tested at a flow rate of 3 GPM at a temperature rise of $77^{\circ} \mathrm{F}$ with $135^{\circ} \mathrm{F}$ outlet water, the same conditions recommended for testing all residential water heaters [4]. If that temperature rise at that flow rate cannot be achieved, then the highest flow rate obtainable by the unit which produces a temperature rise of $77^{\circ} \mathrm{F}$ should 
be used. Units $G, H$, and $I$ can heat water to a temperature rise of $77^{\circ} \mathrm{F}$, at lower flow rates than 3 GPM. Unit F could not achieve a temperature rise of $77^{\circ} \mathrm{F}$ at any flow rate (see Figure 2)。

Because of the incongruity of the GPM versus Temperature Rise curves crossing the $77^{\circ} \mathrm{F}$ temperature rise line, it appears that a single draw test would be inappropriate. The testing of instantaneous water heaters should use a number of draws and temperature rises and be run often enough to characterize the performance of the particular water heater under test. One way of accomplishing this would be by drawing 20 gallons of water at a temperature rise of $80^{\circ} \mathrm{F}, 77^{\circ} \mathrm{F}$, and $75^{\circ} \mathrm{F}$, defined as a draw series, and repeating these draws for a total of three series. This would represent a total of 9 water draws of 20 gallons each. The measured GPM versus Temperature Rise can then be plotted on a graph and the series lines connected. If the intersection of the series lines with the $77^{\circ} \mathrm{F}$ constant temperature rise line (see Figures 2 through 5) is observed to have a GPM spread of 0.2 GPM or less, the average of the three intersections should be used as the GPM output of the instantaneous water heater at a temperature rise of $77^{\circ} \mathrm{F}$.

If the spread is greater than 0.2 GPM, repeat the tests for 3 additional series totaling an additional 9 draws of 21.4 gallons each. These additional measured GPM versus Temperature Rise points are added to the original graph, then the lines are connected and the intersections of the six lines crossing the constant temperature rise line of $77^{\circ} \mathrm{F}$ averaged. The average of these points would represent the 
GPM output of the instantaneous water heater at a temperature rise of $77^{\circ} \mathrm{F}$.

\subsection{Determination of Recovery Efficiency}

The single flow rate required to provide a water temperature rise of $77^{\circ} \mathrm{F}$ should be used to calculate the Er for the water heater. Since the Er as a function of flow rate is fairly constant (see Figure 6, 7, 8, and 9), errors in GPM versus Temperature Rise measurement or inconsistent unit operation due to burner firing tolerances should have little effect on the resulting Er. This procedure should be modified if, for any reason, other units tested exhibit characteristics that are significantly different from these four tested units.

The comparison of $\mathrm{Er}^{\prime} \mathrm{s}$ between instantaneous water heaters seems to be a reasonable index of relative performance. This is true even though the maximum flow rate at a temperature rise of $77^{\circ} \mathrm{F}$ varies among water heaters. Since the Er, as a function of flow rate, is fairly constant, the calculated values should not be significantly affected.

Instantaneous water heaters that do not have the ability to deliver water at a temperature rise of $77^{\circ} \mathrm{F}$ cannot be compared by this index of performance. With regard to the index itself, it is doubtful that a $\operatorname{Er}$ for instantaneous water heaters can be directly compared to a Er for storage type water heaters with any meaning. One difference is that the instantaneous water heater will generally supply less than the 3 GPM flow rate as is used for storage type heaters. Another is that once the flow rate at a temperature rise of $77^{\circ} \mathrm{F}$ for an instantaneous 
water heater is determined, it can produce this flow of hot water indefinitely. This area of comparison needs further investigation and study.

\subsection{Determination of Energy Factor}

Once a flow rate at a temperature rise of $77^{\circ} \mathrm{F}$ is determined, the EF for the unit can be determined given a total daily draw of hot water and the pilot energy consumption rate. Although the EF is somewhat sensitive to flow rate, it seems adequate to determine this index at the, single, representative flow rate at the flow rate output of $77^{\circ} \mathrm{F}$ as described in 4.1. However, the Energy Factor is sensitive to the total water drawn and the pilot light energy consumption rate.

An argument could be made that since instantaneous water heaters are designed to deliver an unlimited supply of hot water at a given temperature rise and flow rate, any index for these units which is based on a specific total water delivery may be misleading. For example, the less water that is used, the lower the EF; although the Er remains the same. And this decrease in Energy Factor is not caused by the operation of the unit but rather by the effects of the energy used by the pilot light.

Another consideration in using the EF as a performance index is that the units are designed to be turned-off, that is, the pilot light is extinguished when the unit is not in use. The pilot lights, however, are easily started by manually operating a push button to activate a piezoelectric spark igniter. Although this mode of operation is common 
overseas, such operation has been basically untested as a viable mode of operation by individuals in the United States who have been conditioned to not having to activate their pilot lights on their storage type water heaters. In considering a performance index, it is questionable as to whether or not the water heater should be penalized by assuming that the user will not make full use of the built-in energy saving potential associated with this type of water heater. As for the pilot energy consumption rate, the point is moot if the pilot light is turned off after each use. This area also requires additional investigation and study to determine its usefulness as a performance index for instantaneous water heaters and as a common denominator to compare the performance of storage type water heaters.

\section{CONCLUSIONS}

Based on an analysis of the data for the tests conducted on four instantaneous water heaters, the following general conclusions are submitted:

1. The actual flow rate characteristics at a temperature rise of $77^{\circ} \mathrm{F}$ for the instantaneous water heaters should be determined by a series of tests.

2. The use of Er as a performance index to compare different instantaneous water heaters seems appropriate.

3. The EF determination for instantaneous water heaters is sensitive to the given total number of gallons drawn, the flow rate, and the pilot light energy consumption rate. 
7. REFERENCES

[1] American National Standard for Gas Water Heaters, Volume 1Automatic Storage Water Heaters with Inputs of 75,000 BTU Per Hour or 1ess - ANSI-221.10.1-1984.

[2] American National Standard for Gas Water Heaters, Volume IIICirculating Tank, Instantaneous, and Large Automatic Storage Water Heaters - ANSI-Z21.10.3-1984.

[3] Federal Register, Vol. 42, No. 192, October 1977, pages 5420054119 , as amended by Federal Register, Vol. 43, No. 203, October 19, 1978, pages 48986-48987 and Federal Register, Vo1. 44, No. 175, September 7, 1979, pages 52632-52640.

[4] Federal Register, Part II, Department of Energy, Office of Conservation and Renewable Energy, 10 CFR part 430, Energy Conservation Program for Water Heaters; Public Hearing; Proposed Rule, pages 4870 - 4889, dated February 8, 1984.

[5] NBSIR 86-3412; DOE/NBS Forum on Testing and Rating Procedures for Consumer Products; October 2-3, 1985; R. D. Dikkers; July 1986. 


\section{INSTANTANEOUS GAS-FIRED WATER HEATER TEST SET-UP}

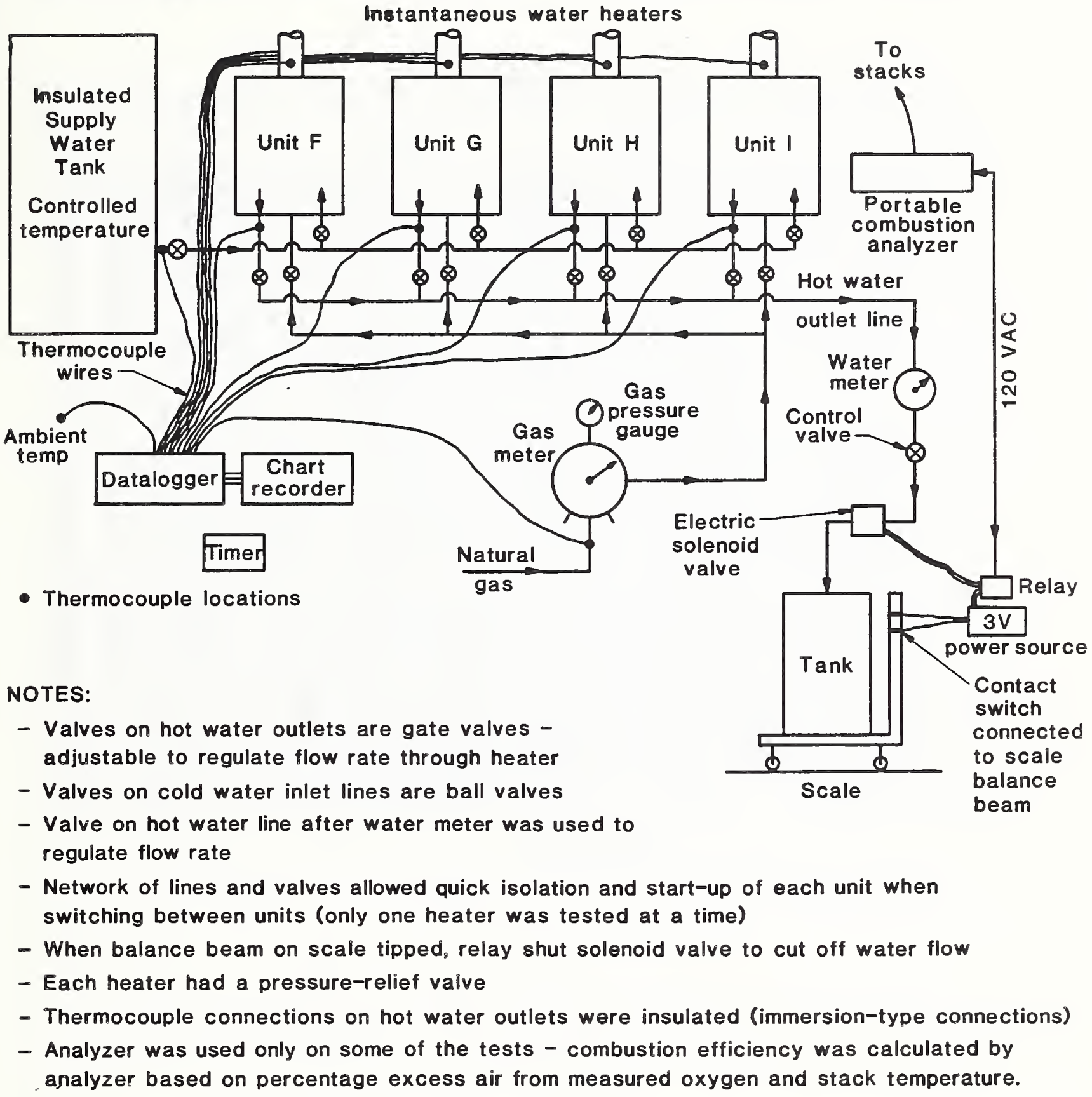

Figure 1. Instantaneous Gas-Fired Water Heater Test Set-Up. 
Table 1a. Test Data - Unit F

TEST DATA - UNIT F

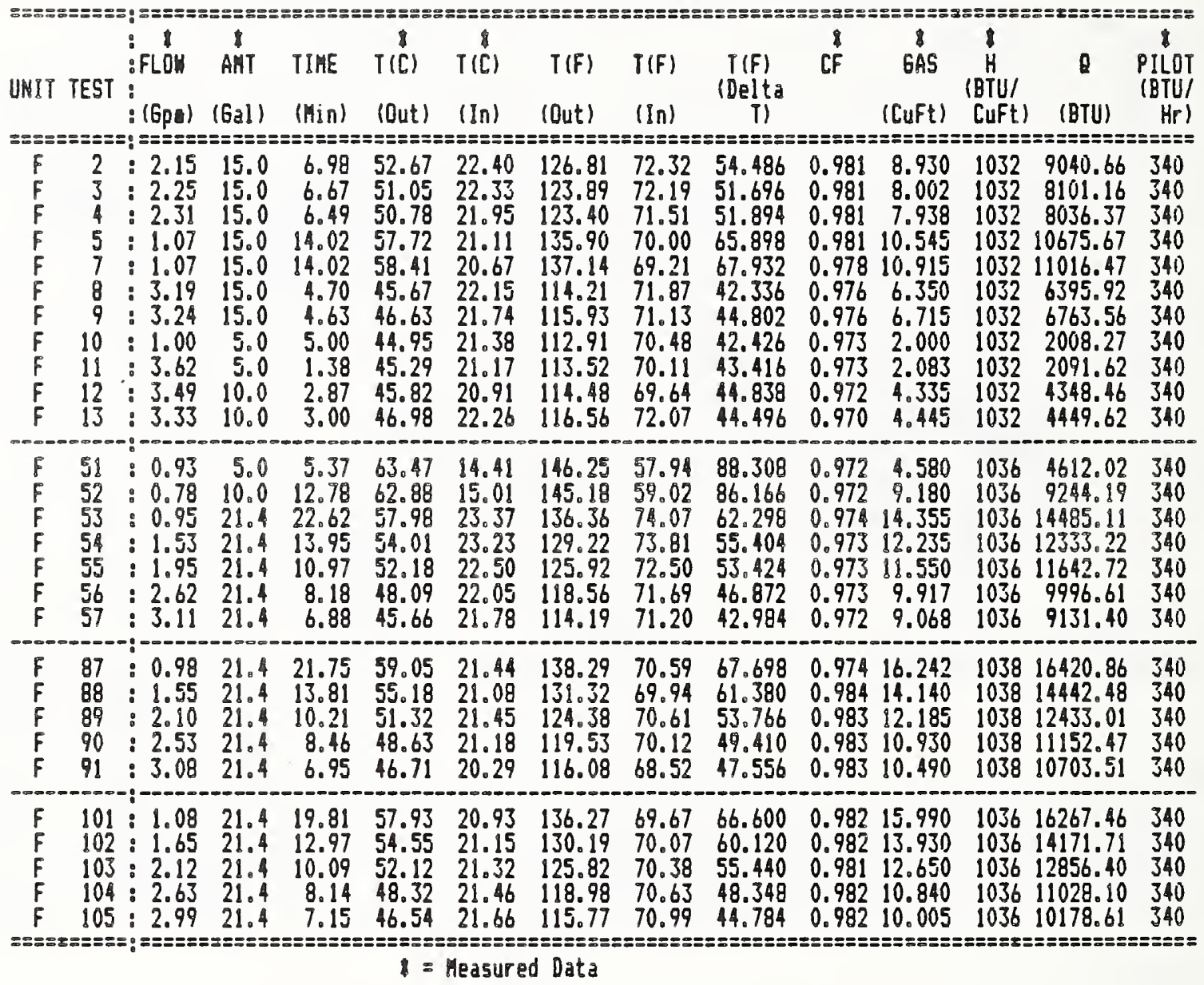


Table 1b. Test Data - Unit G

TEST DATA - UNIT 6

\begin{tabular}{|c|c|c|c|c|c|c|c|c|c|c|c|c|c|c|}
\hline UNIT & & $\begin{array}{l}\vdots \\
\vdots \text { FLOH } \\
\vdots \\
\text { (600) }\end{array}$ & $\begin{array}{c}t \\
A M T\end{array}$ & TIME & $T(C)$ & $\begin{array}{c}1 \\
T(C)\end{array}$ & $T(F)$ & $T(F)$ & $\begin{array}{c}T(F) \\
\text { (Delta } \\
T)\end{array}$ & $C F$ & $\begin{array}{c}t \\
\text { GAS } \\
\text { (CuFt) }\end{array}$ & $\begin{array}{c}H \\
\text { (BTU) } \\
\text { CuFt) }\end{array}$ & $\begin{array}{c}\theta \\
\text { (BTU) }\end{array}$ & $\begin{array}{c}8 \\
\text { PILOT } \\
\text { (BTU) } \\
\text { Hr) }\end{array}$ \\
\hline $\begin{array}{l}6 \\
6 \\
6 \\
6\end{array}$ & $\begin{array}{l}29 \\
30 \\
31 \\
32\end{array}$ & $\begin{array}{l}2.22 \\
: 2.11 \\
: 2.07 \\
: 1.63\end{array}$ & $\begin{array}{l}5.0 \\
5.0 \\
5.0 \\
5.0\end{array}$ & $\begin{array}{l}2 . \\
2 . \\
2 . \\
3 .\end{array}$ & $\begin{array}{l}5 \\
5 \\
6 \\
6\end{array}$ & $\begin{array}{l}20 . \\
21 . \\
21 .\end{array}$ & & & & & & & & $\begin{array}{l}357 \\
357 \\
357 \\
357\end{array}$ \\
\hline & $\begin{array}{l}58 \\
59 \\
60 \\
61 \\
62\end{array}$ & $\begin{array}{l}1.01 \\
1.65 \\
2.10 \\
2.53 \\
3.16\end{array}$ & $\begin{array}{l}21.4 \\
21.4 \\
21.4 \\
21.4 \\
21.4\end{array}$ & $\begin{array}{r}21 . \\
12 . \\
10 . \\
8 . \\
6 .\end{array}$ & $\begin{array}{l}61 \\
69 \\
60 \\
54 \\
47\end{array}$ & $\begin{array}{l}21 \\
21 \\
21 \\
21 \\
21\end{array}$ & & & & & & & & $\begin{array}{l}357 \\
357 \\
357 \\
357 \\
357\end{array}$ \\
\hline $\begin{array}{l}6 \\
6 \\
6 \\
6 \\
6 \\
6\end{array}$ & $\begin{array}{l}79 \\
80 \\
81 \\
82 \\
83 \\
84 \\
85 \\
86\end{array}$ & 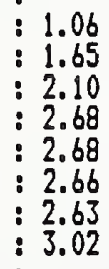 & $\begin{array}{l}21.4 \\
21.4 \\
21.4 \\
21.4 \\
21.4 \\
50.0 \\
50.0 \\
21.4\end{array}$ & $\begin{array}{r}20.19 \\
12.97 \\
10.19 \\
7.98 \\
7.98 \\
18.77 \\
18.98 \\
7.08\end{array}$ & $\begin{array}{l}62.87 \\
66.91 \\
59.79 \\
51.56 \\
51.18 \\
50.88 \\
50.64 \\
48.87\end{array}$ & $\begin{array}{l}20 . \\
21 . \\
21 . \\
20 . \\
19 . \\
21 .\end{array}$ & & & & & & & & $\begin{array}{l}357 \\
357 \\
357 \\
357 \\
357 \\
357 \\
357 \\
357\end{array}$ \\
\hline $\begin{array}{l}6 \\
6 \\
6 \\
6 \\
6 \\
6 \\
6\end{array}$ & $\begin{array}{l}106 \\
107 \\
108 \\
109 \\
110 \\
111\end{array}$ & $: 1.06$ & $\begin{array}{l}21 \\
21 \\
21 \\
21 \\
21 \\
21\end{array}$ & $\begin{array}{l}20 . \\
15 . \\
13 . \\
11 . \\
10 . \\
8 . \\
6 .\end{array}$ & $\begin{array}{l}62.5 \\
62.5 \\
66.9 \\
65.9 \\
61.5 \\
53.3\end{array}$ & $\begin{array}{l}21.9 \\
22 . \\
22 . \\
22 . \\
22.5\end{array}$ & $\begin{array}{l}144 \\
143 \\
152 \\
150 \\
142 \\
127 \\
110\end{array}$ & $\begin{array}{l}71 \\
71 \\
72 \\
72 \\
72 \\
72\end{array}$ & $\begin{array}{l}73 . \\
71 . \\
80 . \\
78 . \\
70 . \\
55 .\end{array}$ & $\begin{array}{l}0 . \\
0 . \\
0 . \\
0 . \\
0 . \\
0 . \\
0 .\end{array}$ & & & & $\begin{array}{l}357 \\
357 \\
357 \\
357 \\
357 \\
357 \\
357\end{array}$ \\
\hline
\end{tabular}


Table 1c. Test Data - Unit $\mathrm{H}$

TEST DATA - UNIT H

\begin{tabular}{|c|c|c|c|c|c|c|c|c|c|c|c|c|c|c|}
\hline UNIT & TEST & $\begin{array}{c}1 \\
: F L O H \\
:(6 p D)\end{array}$ & $\begin{array}{c}1 \\
\text { AMT }\end{array}$ & TIHE & $\begin{array}{c}t \\
T(C) \\
\text { (Out) }\end{array}$ & $T(C)$ & $\begin{array}{l}T(F) \\
\text { (Qut) }\end{array}$ & $(\ln )$ & $\begin{array}{c}\text { T(F) } \\
\text { (Delta } \\
\text { T) }\end{array}$ & CF & $\begin{array}{c}\text { GAS } \\
\text { (CuFt) }\end{array}$ & $\begin{array}{c}t \\
H \\
\text { (BTU/ } \\
\text { CuFt) }\end{array}$ & $\begin{array}{c}\theta \\
\text { (BTU) }\end{array}$ & $\begin{array}{c}\text { PILD } \\
\text { IBTU } \\
\text { Hr }\end{array}$ \\
\hline $\begin{array}{l}H \\
H \\
H \\
H \\
H \\
H \\
H \\
H \\
H \\
H \\
H \\
H \\
H \\
H \\
H\end{array}$ & $\begin{array}{l}14 \\
15 \\
16 \\
17 \\
18 \\
19 \\
20 \\
21 \\
22 \\
23 \\
24 \\
25 \\
26 \\
27 \\
28\end{array}$ & $\begin{array}{l}1.28 \\
1.36 \\
3.86 \\
3.84 \\
1.83 \\
1.78 \\
4.07 \\
3.99 \\
2.34 \\
2.38 \\
1.37 \\
1.59 \\
3.00 \\
2.08 \\
3.49\end{array}$ & $\begin{array}{r}5.0 \\
5.0 \\
14.2 \\
14.1 \\
5.0 \\
5.0 \\
11.3 \\
11.1 \\
5.0 \\
5.0 \\
5.0 \\
5.0 \\
5.0 \\
5.0 \\
5.0\end{array}$ & $\begin{array}{l}3.92 \\
3.67 \\
3.67 \\
3.67 \\
2.73 \\
2.82 \\
2.78 \\
2.78 \\
2.13 \\
2.10 \\
3.66 \\
3.15 \\
1.67 \\
2.40 \\
1.43\end{array}$ & $\begin{array}{l}67.94 \\
67.98 \\
47.48 \\
47.00 \\
64.55 \\
64.52 \\
45.84 \\
46.70 \\
60.58 \\
60.65 \\
67.34 \\
65.87 \\
52.63 \\
62.24 \\
48.58\end{array}$ & $\begin{array}{l}21.50 \\
21.50 \\
21.50 \\
21.40 \\
21.38 \\
21.40 \\
21.42 \\
21.40 \\
21.78 \\
21.73 \\
21.69 \\
21.57 \\
21.38 \\
21.24 \\
21.08\end{array}$ & $\begin{array}{l}154.29 \\
154.36 \\
117.46 \\
116.60 \\
148.19 \\
148.14 \\
114.51 \\
116.06 \\
141.04 \\
141.17 \\
153.22 \\
150.57 \\
126.73 \\
144.03 \\
119.44\end{array}$ & $\begin{array}{l}70.70 \\
70.70 \\
70.70 \\
70.52 \\
70.48 \\
70.52 \\
70.56 \\
70.52 \\
71.20 \\
71.11 \\
71.03 \\
70.83 \\
70.48 \\
70.23 \\
69.94\end{array}$ & $\begin{array}{l}83.592 \\
83.664 \\
46.764 \\
46.080 \\
77.706 \\
77.616 \\
43.956 \\
45.540 \\
69.840 \\
70.065 \\
82.181 \\
79.740 \\
56.250 \\
73.800 \\
49.500\end{array}$ & $\begin{array}{l}0.973 \\
0.969 \\
0.967 \\
0.965 \\
0.969 \\
0.968 \\
0.966 \\
0.967 \\
0.963 \\
0.962 \\
0.965 \\
0.965 \\
0.962 \\
0.963 \\
0.962\end{array}$ & $\begin{array}{l}4.555 \\
4.570 \\
6.850 \\
6.845 \\
4.150 \\
4.095 \\
5.110 \\
5.165 \\
3.690 \\
3.640 \\
4.590 \\
4.300 \\
2.920 \\
3.885 \\
2.560\end{array}$ & $\begin{array}{l}1035 \\
1035 \\
1035 \\
1035 \\
1035 \\
1035 \\
1035 \\
1035 \\
1035 \\
1035 \\
1035 \\
1035 \\
1035 \\
1035 \\
1035\end{array}$ & $\begin{array}{l}4587.14 \\
4583.32 \\
6855.79 \\
6836.61 \\
4162.10 \\
4102.70 \\
5109.03 \\
5169.36 \\
3677.84 \\
3624.24 \\
4584.38 \\
4294.73 \\
2907.36 \\
3872.20 \\
2548.92\end{array}$ & 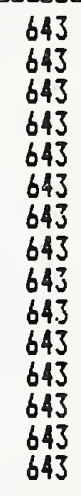 \\
\hline $\begin{array}{l}H \\
H \\
H \\
H \\
H \\
H \\
H\end{array}$ & $\begin{array}{l}40 \\
41 \\
42 \\
43 \\
44 \\
45 \\
46\end{array}$ & $\begin{array}{l}2.21 \\
2.21 \\
1.10 \\
1.04 \\
1.01 \\
1.61 \\
2.30\end{array}$ & $\begin{array}{l}7.5 \\
7.5 \\
7.5 \\
7.5 \\
7.5 \\
7.5 \\
7.5\end{array}$ & $\begin{array}{l}3.39 \\
3.39 \\
6.80 \\
7.23 \\
7.43 \\
4.65 \\
3.27\end{array}$ & $\begin{array}{l}58.30 \\
57.54 \\
57.27 \\
60.33 \\
61.41 \\
61.17 \\
60.73\end{array}$ & $\begin{array}{l}14.49 \\
14.59 \\
15.21 \\
15.88 \\
13.36 \\
13.78 \\
13.11\end{array}$ & $\begin{array}{l}136.94 \\
135.57 \\
135.09 \\
140.59 \\
142.54 \\
142.11 \\
141.31\end{array}$ & $\begin{array}{l}58.08 \\
58.26 \\
59.39 \\
60.58 \\
56.05 \\
56.80 \\
55.60\end{array}$ & $\begin{array}{l}77 . \\
75 . \\
80 . \\
86 . \\
85 . \\
85 .\end{array}$ & & $\begin{array}{l}40 \\
20 \\
00 \\
70 \\
20 \\
35 \\
55\end{array}$ & $\begin{array}{l}1036 \\
1036 \\
1036 \\
1036 \\
1036 \\
1036 \\
1036\end{array}$ & $\begin{array}{l}8.49 \\
7.53 \\
0.57 \\
9.97 \\
6.36 \\
3.92 \\
6.27\end{array}$ & \\
\hline $\begin{array}{l}H \\
H \\
H \\
H \\
H\end{array}$ & $\begin{array}{l}63 \\
64 \\
65 \\
66 \\
67\end{array}$ & $\begin{array}{l}1.05 \\
1.65 \\
: 2.05 \\
: 2.53 \\
3.13\end{array}$ & $\begin{array}{l}21.4 \\
21.4 \\
21.4 \\
21.4 \\
21.4\end{array}$ & $\begin{array}{l}20.48 \\
12.97 \\
10.44 \\
8.46 \\
6.83\end{array}$ & $\begin{array}{l}68.98 \\
62.30 \\
61.59 \\
57.88 \\
52.86\end{array}$ & $\begin{array}{l}22.26 \\
22.14 \\
21.64 \\
21.60 \\
21.46\end{array}$ & $\begin{array}{l}158 \\
144 \\
142 \\
138 \\
127\end{array}$ & $\begin{array}{l}72 . \\
71 . \\
70 . \\
70 . \\
70 .\end{array}$ & $\begin{array}{l}84.096 \\
72.283 \\
71.910 \\
65.304 \\
56.520\end{array}$ & $\begin{array}{l}0 . \\
0 . \\
0 . \\
0 . \\
0 .\end{array}$ & $\begin{array}{l}95 \\
50 \\
55 \\
55 \\
25 \\
70\end{array}$ & $\begin{array}{l}1036 \\
1036 \\
1036 \\
1036 \\
1036\end{array}$ & $\begin{array}{l}31 \\
43 \\
51 \\
47 \\
10\end{array}$ & \\
\hline $\begin{array}{l}H \\
H \\
H \\
H \\
H\end{array}$ & $\begin{array}{l}92 \\
93 \\
94 \\
95 \\
96\end{array}$ & $\begin{array}{l}1.04 \\
: 1.64 \\
2.13 \\
2.55 \\
: 3.17\end{array}$ & $\begin{array}{l}21.4 \\
21.4 \\
21.4 \\
21.4 \\
21.4\end{array}$ & $\begin{array}{r}20.58 \\
13.05 \\
10.05 \\
8.39 \\
6.75\end{array}$ & $\begin{array}{l}71.77 \\
66.44 \\
62.38 \\
58.78 \\
52.01\end{array}$ & $\begin{array}{l}21.25 \\
21.34 \\
20.80 \\
21.09 \\
21.28\end{array}$ & $\begin{array}{l}101 \\
151 \\
14 \\
137 \\
125\end{array}$ & $\begin{array}{l}70.25 \\
70.41 \\
69.44 \\
69.96 \\
70.30\end{array}$ & $\begin{array}{l}90.936 \\
81.180 \\
74.844 \\
67.842 \\
55.314\end{array}$ & $\begin{array}{l}0.974 \\
0.976 \\
0.977 \\
0.975 \\
0.974\end{array}$ & & $\begin{array}{l}1038 \\
1038 \\
1038 \\
1038 \\
1038\end{array}$ & & \\
\hline $\begin{array}{l}H \\
H \\
H \\
H \\
H \\
H \\
==0=\end{array}$ & $\begin{array}{l}113 \\
114 \\
115 \\
116 \\
117 \\
118\end{array}$ & $\begin{array}{l}1.06 \\
1.33 \\
2.09 \\
2.64 \\
3.06\end{array}$ & $\begin{array}{l}21.4 \\
21.4 \\
21.4 \\
21.0 \\
21.4 \\
21.4\end{array}$ & $\begin{array}{l}20.38 \\
12.74 \\
16.09 \\
10.07 \\
8.11 \\
6.99\end{array}$ & $\begin{array}{l}71.15 \\
65.27 \\
68.06 \\
63.08 \\
57.44 \\
53.39\end{array}$ & $\begin{array}{l}22.61 \\
22.60 \\
22.59 \\
22.10 \\
22.31 \\
22.50\end{array}$ & $\begin{array}{l}160.07 \\
149.49 \\
154.51 \\
145.54 \\
135.39 \\
128.10\end{array}$ & $\begin{array}{l}72.70 \\
72.68 \\
72.66 \\
71.78 \\
72.16 \\
72.50\end{array}$ & $\begin{array}{l}87.372 \\
76.806 \\
81.846 \\
73.764 \\
63.234 \\
55.602\end{array}$ & $\begin{array}{l}0.984 \\
0.982 \\
0.982 \\
0.969 \\
0.969 \\
0.969\end{array}$ & $\begin{array}{l}0.990 \\
7.760 \\
9.390 \\
7.040 \\
4.655 \\
2.790\end{array}$ & $\begin{array}{l}1036 \\
1036 \\
1036 \\
1036 \\
1036 \\
1036\end{array}$ & $\begin{array}{l}.71 \\
.17 \\
.46 \\
.18 \\
.92 \\
.68\end{array}$ & 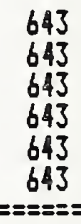 \\
\hline
\end{tabular}


Table 1d. Test Data - Unit I

TEST DATA - UNIT I

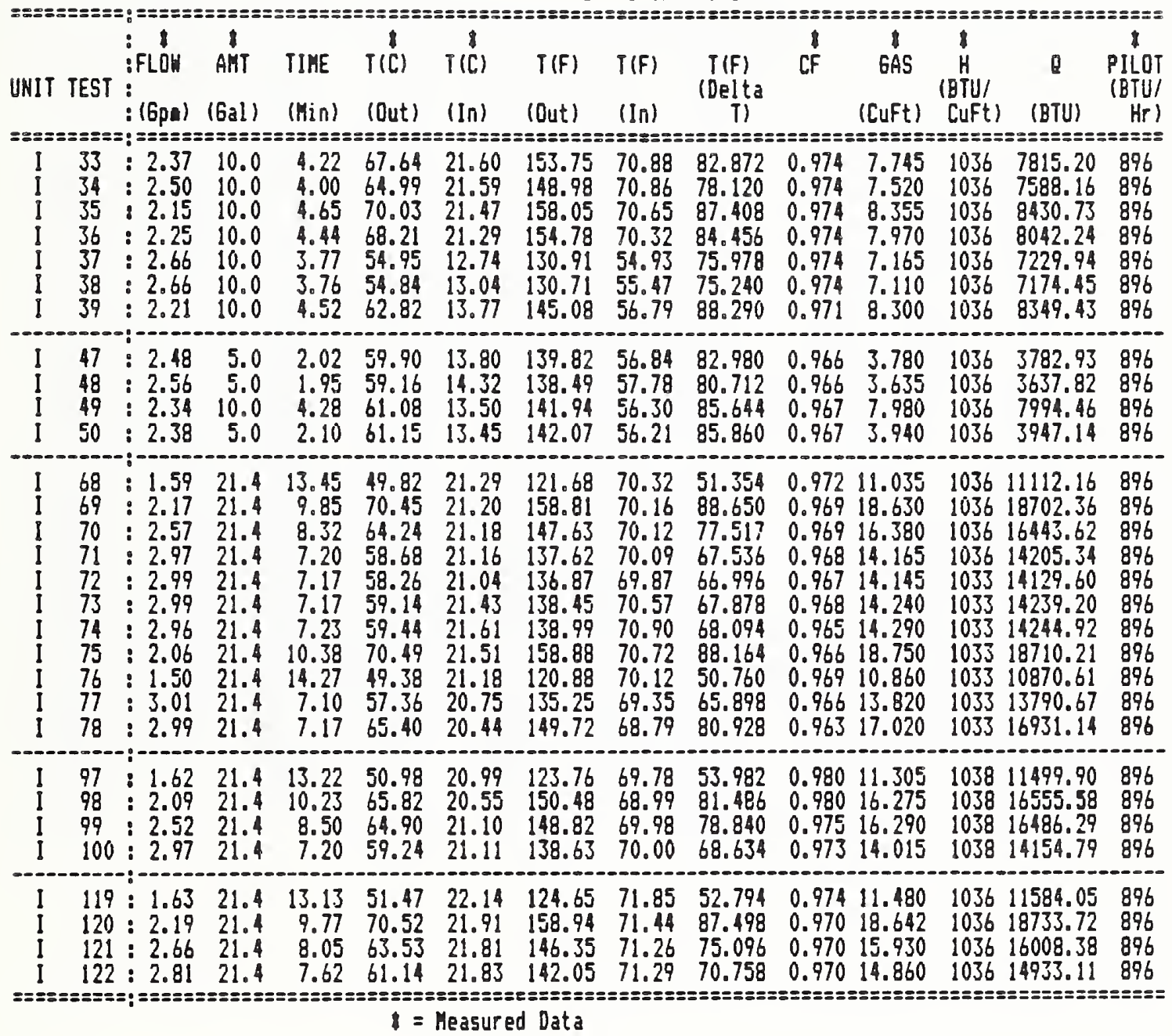


Table 2a. Summary Data, Er, and EF - Unit F

SUMMARY - UNIT F

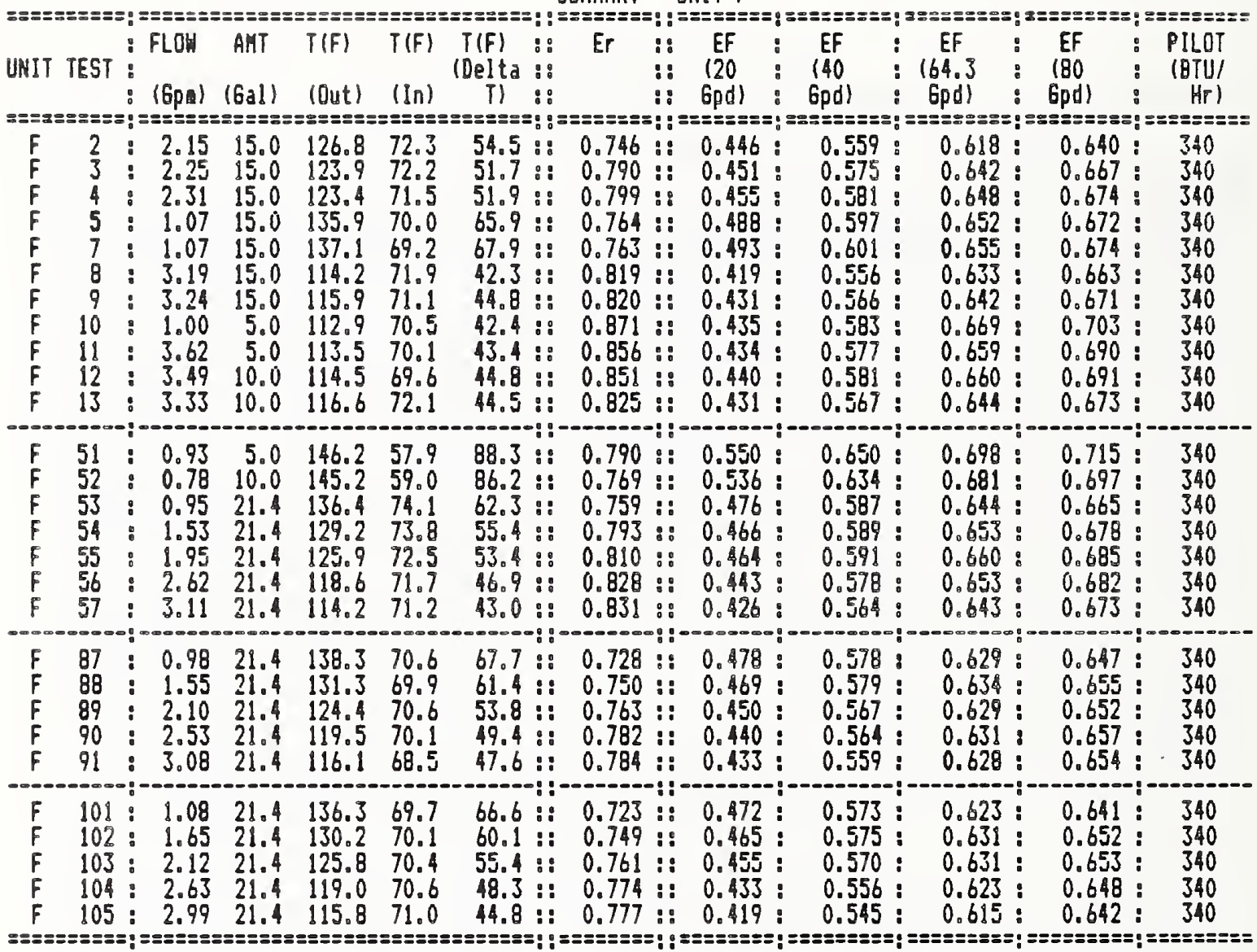


SUMMARY - UHIT 6

\begin{tabular}{|c|c|c|c|c|c|c|c|c|c|c|c|c|c|c|c|c|c|}
\hline UNIT & TEST & $\begin{array}{l}: \text { FLOH } \\
:(6 p \text { al }) \\
:====\end{array}$ & $\begin{array}{l}(6 a)) \\
:=== \pm=\end{array}$ & $\begin{array}{l}\text { (Out) } \\
==== \pm=\end{array}$ & $\begin{array}{l}T(F) \\
(I n) \\
== \pm==\end{array}$ & $\begin{array}{c}T(F) \\
(D E l \text { ta } \\
T) \\
======\end{array}$ & $\begin{array}{l}\therefore: \\
\therefore: \\
\vdots: \\
=:\end{array}$ & $\begin{array}{c}\text { Er } \\
\text { s= }\end{array}$ & $\begin{array}{l}a: \\
\vdots: \\
\vdots: \\
::\end{array}$ & $\begin{array}{l}\text { EF } \\
(20 \\
6 p d) \\
=====\end{array}$ & $\begin{array}{l}: \\
\vdots \\
i\end{array}$ & $\begin{array}{l}E F \\
(40 \\
\text { Epd) } \\
======\end{array}$ & $\begin{array}{c}\vdots \\
\vdots \\
\vdots \\
:\end{array}$ & $\begin{array}{c}E F \\
(64.3 \\
6 p d) \\
==8===\end{array}$ & $\begin{array}{c}E F \\
180 \\
: \quad 6 p d) \\
:=====\end{array}$ & $\begin{array}{l}\vdots \\
\vdots \\
\vdots \\
=\end{array}$ & $\begin{array}{c}\text { PILOT } \\
\text { (BTU/ } \\
\text { Hr) }\end{array}$ \\
\hline $\begin{array}{l}6 \\
6 \\
6 \\
6\end{array}$ & $\begin{array}{l}29 \\
30 \\
31 \\
32\end{array}$ & $\begin{array}{l}2.22 \\
: \quad 2.11 \\
: \quad 2.07 \\
: \quad 1.63\end{array}$ & $\begin{array}{l}5.0 \\
5.0 \\
5.0 \\
5.0\end{array}$ & $\begin{array}{l}134.5 \\
139.9 \\
140.4 \\
153.5\end{array}$ & $\begin{array}{l}69.4 \\
69.8 \\
70.0 \\
70.2\end{array}$ & $\begin{array}{l}65.1 \\
70.1 \\
70.5 \\
83.3\end{array}$ & $\begin{array}{l}\because \vdots \\
\vdots i \\
a \\
a\end{array}$ & $\begin{array}{l}0.783 \\
0.800 \\
0.793 \\
0.784\end{array}$ & $\begin{array}{l}\because: \\
\because: \\
\because: \\
\because:\end{array}$ & $\begin{array}{l}0.483 \\
0.503 \\
0.502 \\
0.528\end{array}$ & $:$ & $\begin{array}{l}0.599 \\
0.619 \\
0.615 \\
0.632\end{array}$ & $:$ & $\begin{array}{l}0.658 \\
0.678 \\
0.673 \\
0.683\end{array}$ & $\begin{array}{l}0.680 \\
0.699 \\
0.694 \\
0.701\end{array}$ & : & $\begin{array}{l}357 \\
357 \\
357 \\
357\end{array}$ \\
\hline $\begin{array}{l}6 \\
6 \\
6 \\
6 \\
6\end{array}$ & $\begin{array}{l}58 \\
59 \\
60 \\
61 \\
62\end{array}$ & $\begin{array}{l}1.01 \\
1.65 \\
2.10 \\
2.53 \\
3.16\end{array}$ & $\begin{array}{l}21.4 \\
21.4 \\
21.4 \\
21.4 \\
21.4\end{array}$ & $\begin{array}{l}142.7 \\
156.2 \\
140.8 \\
129.4 \\
117.2\end{array}$ & $\begin{array}{l}71.0 \\
70.8 \\
70.8 \\
70.8 \\
70.7\end{array}$ & $\begin{array}{l}71.7 \\
85.4 \\
70.0 \\
58.6 \\
46.5\end{array}$ & $\begin{array}{l}:: \\
\therefore: \\
a: \\
\vdots: \\
a:\end{array}$ & $\begin{array}{l}0.780 \\
0.824 \\
0.828 \\
0.833 \\
0.833\end{array}$ & $\begin{array}{l}a: \\
\vdots: \\
\vdots \\
\vdots \\
\therefore:\end{array}$ & $\begin{array}{l}0.501 \\
0.550 \\
0.514 \\
0.480 \\
0.433\end{array}$ & : & $\begin{array}{l}0.612 \\
0.661 \\
0.636 \\
0.610 \\
0.570\end{array}$ & $\begin{array}{l}\vdots \\
\vdots \\
\vdots \\
\vdots\end{array}$ & $\begin{array}{l}0.668 \\
0.715 \\
0.698 \\
0.680 \\
0.648\end{array}$ & $\begin{array}{l}0.688 \\
0.735 \\
0.720 \\
0.706 \\
0.678\end{array}$ & $\begin{array}{l}\vdots \\
\vdots \\
\vdots \\
:\end{array}$ & $\begin{array}{l}357 \\
357 \\
357 \\
357 \\
357\end{array}$ \\
\hline $\begin{array}{l}6 \\
6 \\
6 \\
6 \\
6 \\
6 \\
6 \\
6\end{array}$ & $\begin{array}{l}79 \\
80 \\
81 \\
82 \\
83 \\
84 \\
85 \\
86\end{array}$ & $\begin{array}{l}1.06 \\
1.65 \\
2.10 \\
2.68 \\
2.68 \\
: \quad 2.66 \\
2.63 \\
: 3.02\end{array}$ & $\begin{array}{l}21.4 \\
21.4 \\
21.4 \\
21.4 \\
21.4 \\
50.0 \\
50.0 \\
21.4\end{array}$ & $\begin{array}{l}145.2 \\
152.4 \\
139.6 \\
124.8 \\
124.1 \\
123.6 \\
123.2 \\
120.0\end{array}$ & $\begin{array}{l}70.6 \\
69.6 \\
70.2 \\
69.9 \\
69.4 \\
68.3 \\
67.4 \\
70.8\end{array}$ & & $\begin{array}{l}\vdots: \\
\therefore: \\
\vdots: \\
\vdots: \\
\therefore: \\
\vdots: \\
\vdots: \\
\therefore:\end{array}$ & $\begin{array}{l}0.762 \\
0.786 \\
0.794 \\
0.774 \\
0.775 \\
0.779 \\
0.781 \\
0.784\end{array}$ & $\begin{array}{l}\vdots: \\
\therefore: \\
\therefore: \\
\therefore: \\
\vdots: \\
\vdots: \\
\vdots: \\
\therefore:\end{array}$ & $\begin{array}{l}0.500 \\
0.528 \\
0.500 \\
0.448 \\
0.448 \\
0.451 \\
0.453 \\
0.430\end{array}$ & $\begin{array}{l}\vdots \\
\vdots \\
\vdots \\
\vdots \\
\vdots \\
\vdots\end{array}$ & $\begin{array}{l}0.605 \\
0.633 \\
0.614 \\
0.568 \\
0.568 \\
0.572 \\
0.574 \\
0.556\end{array}$ & $\begin{array}{l}\vdots \\
\vdots \\
\vdots \\
\vdots \\
\vdots \\
\vdots\end{array}$ & $\begin{array}{l}0.658 \\
0.684 \\
0.673 \\
0.632 \\
0.633 \\
0.637 \\
0.639 \\
0.625\end{array}$ & $\begin{array}{l}0.677 \\
0.703 \\
0.694 \\
0.656 \\
0.657 \\
0.661 \\
0.663 \\
0.652\end{array}$ & $\begin{array}{l}\vdots \\
\vdots \\
\vdots \\
\vdots \\
\vdots\end{array}$ & $\begin{array}{l}357 \\
357 \\
357 \\
357 \\
357 \\
357 \\
357 \\
357\end{array}$ \\
\hline $\begin{array}{l}6 \\
6 \\
6 \\
6 \\
6 \\
6 \\
6\end{array}$ & $\begin{array}{l}106 \\
107 \\
108 \\
109 \\
110 \\
111 \\
112\end{array}$ & $\begin{array}{l}1.06 \\
1.35 \\
1.63 \\
1.87 \\
2.08 \\
2.64 \\
3\end{array}$ & $\begin{array}{l}21.4 \\
21.4 \\
21.4 \\
21.4 \\
21.4 \\
21.4 \\
21.4\end{array}$ & $\begin{array}{l}144.6 \\
143.7 \\
152.5 \\
150.7 \\
142.8 \\
128.0 \\
119.5\end{array}$ & $\begin{array}{l}71.4 \\
71.9 \\
72.2 \\
72.4 \\
72.6 \\
72.7 \\
72.7\end{array}$ & $\begin{array}{l}55.3 \\
46.9\end{array}$ & $\begin{array}{l}:: \\
\vdots: \\
\vdots: \\
\vdots: \\
\vdots: \\
\vdots: \\
\vdots:\end{array}$ & $\begin{array}{l}0.737 \\
0.750 \\
0.770 \\
0.786 \\
0.781 \\
0.782 \\
0.790\end{array}$ & $\begin{array}{l}:: \\
:: \\
:: \\
:: \\
:: \\
\vdots: \\
::\end{array}$ & $\begin{array}{l}0.486 \\
0.488 \\
0.516 \\
0.518 \\
0.496 \\
0.452 \\
0.422\end{array}$ & $\begin{array}{l}\vdots \\
\vdots \\
i \\
\vdots \\
i\end{array}$ & $\begin{array}{l}0.588 \\
0.592 \\
0.619 \\
0.625 \\
0.608 \\
0.574 \\
0.551 \\
\end{array}$ & $\begin{array}{l}: \\
\vdots \\
\vdots \\
\vdots \\
\vdots\end{array}$ & $\begin{array}{l}0.638 \\
0.645 \\
0.669 \\
0.678 \\
0.664 \\
0.639 \\
0.623\end{array}$ & $\begin{array}{ll}0 & 0.656 \\
0 & 0.663 \\
0 & 0.687 \\
0 & 0.698 \\
0 & 0.685 \\
0 & 0.663 \\
0 & 0.650\end{array}$ & : & $\begin{array}{l}357 \\
357 \\
357 \\
357 \\
357 \\
357 \\
357\end{array}$ \\
\hline
\end{tabular}


Table 2c. Summary Data, Er, and EF - Unit H

SUMMARY - UNIT H

\begin{tabular}{|c|c|c|c|c|c|c|c|c|c|c|c|c|c|c|c|c|c|}
\hline UNIT & TEST & $\begin{array}{l}\text { FLOH } \\
\text { (6pel }) \\
===\approx==\end{array}$ & AMT & $\begin{array}{l}\text { (Out) } \\
\text { ses=s }\end{array}$ & $\begin{array}{c}(\ln ) \\
==== \pm=\end{array}$ & $\begin{array}{c}\text { T(F) } \\
\text { (Delta } \\
\text { T) } \\
\text { (D) }\end{array}$ & $\begin{array}{l}\vdots: \\
i: \\
\vdots: \\
8::=\end{array}$ & $== \pm= \pm=$ & $\begin{array}{l}a: \\
\vdots: \\
\therefore: \\
=::=\end{array}$ & $\begin{array}{l}E F \\
120 \\
\text { Gpd) } \\
===5==\end{array}$ & $\begin{array}{l}\vdots \\
\vdots \\
\vdots\end{array}$ & $\begin{array}{l}\text { EF } \\
(40 \\
\text { Gpd) } \\
==\approx===\end{array}$ & : & $\begin{array}{c}\text { EF } \\
(64.3 \\
\text { Gpd) } \\
======\end{array}$ & $:$ & $\begin{array}{c}\text { EF } \\
(80) \\
6 p d) \\
0= \pm== \pm=\end{array}$ & $\begin{array}{c}\text { PILOT } \\
\text { (ETU/ } \\
\text { Hr) } \\
:=== \pm===\end{array}$ \\
\hline $\begin{array}{l}H \\
H \\
H \\
H \\
H \\
H \\
H \\
H \\
H \\
H \\
H \\
H \\
H \\
H \\
H\end{array}$ & $\begin{array}{l}14: \\
15: \\
16: \\
17: \\
18: \\
19: \\
20: \\
21: \\
22: \\
23: \\
24: \\
25: \\
26: \\
27: \\
28:\end{array}$ & $\begin{array}{l}1.28 \\
1.36 \\
3.86 \\
3.84 \\
1.83 \\
1.78 \\
4.07 \\
3.99 \\
2.34 \\
2.38 \\
1.37 \\
1.59 \\
3.00 \\
2.08 \\
3.49\end{array}$ & $\begin{array}{r}5.0 \\
5.0 \\
14.2 \\
14.1 \\
5.0 \\
5.0 \\
11.3 \\
11.1 \\
5.0 \\
5.0 \\
5.0 \\
5.0 \\
5.0 \\
5.0 \\
5.0\end{array}$ & $\begin{array}{l}154.3 \\
154.4 \\
117.5 \\
116.6 \\
148.2 \\
148.1 \\
114.5 \\
116.1 \\
141.0 \\
141.2 \\
153.2 \\
150.6 \\
126.7 \\
144.0 \\
119.4\end{array}$ & $\begin{array}{l}70.7 \\
70.7 \\
70.7 \\
70.5 \\
70.5 \\
70.5 \\
70.6 \\
70.5 \\
71.2 \\
71.1 \\
71.0 \\
70.8 \\
70.5 \\
70.2 \\
69.9\end{array}$ & $\begin{array}{l}83.6 \\
83.7 \\
46.8 \\
46.1 \\
77.7 \\
77.6 \\
44.0 \\
45.5 \\
69.8 \\
70.1 \\
82.2 \\
79.7 \\
56.3 \\
73.8 \\
49.5\end{array}$ & 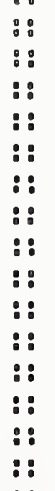 & $\begin{array}{l}0.752 \\
0.753 \\
0.796 \\
0.782 \\
0.770 \\
0.780 \\
0.803 \\
0.807 \\
0.783 \\
0.797 \\
0.739 \\
0.766 \\
0.798 \\
0.786 \\
0.801\end{array}$ & 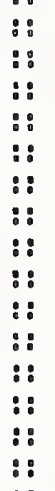 & $\begin{array}{l}0.110 \\
0.411 \\
0.308 \\
0.303 \\
0.401 \\
0.404 \\
0.297 \\
0.304 \\
0.383 \\
0.387 \\
0.403 \\
0.405 \\
0.344 \\
0.395 \\
0.319\end{array}$ & $\begin{array}{l}\vdots \\
\vdots \\
\vdots \\
\vdots \\
\vdots \\
\vdots \\
\vdots \\
\vdots \\
\vdots \\
\vdots \\
\vdots \\
\vdots\end{array}$ & $\begin{array}{l}0.533 \\
0.533 \\
0.445 \\
0.437 \\
0.529 \\
0.533 \\
0.435 \\
0.443 \\
0.516 \\
0.523 \\
0.524 \\
0.531 \\
0.482 \\
0.527 \\
0.458\end{array}$ & $\begin{array}{l}: \\
: \\
\vdots \\
\vdots \\
\vdots \\
: \\
: \\
:\end{array}$ & $\begin{array}{l}0.600: \\
0.601: \\
0.535: \\
0.525: \\
0.601: \\
0.607: \\
0.527: \\
0.534: \\
0.593: \\
0.602: \\
0.590: \\
0.602: \\
0.567: \\
0.603: \\
0.547:\end{array}$ & $:$ & $\begin{array}{l}0.626 \\
0.627 \\
0.572: \\
0.562: \\
0.629: \\
0.636: \\
0.565: \\
0.573: \\
0.624: \\
0.633: \\
0.615: \\
0.629: \\
0.602: \\
0.633: \\
0.584:\end{array}$ & $\begin{array}{l}643 \\
643 \\
643 \\
643 \\
643 \\
643 \\
643 \\
643 \\
643 \\
643 \\
643 \\
643 \\
643 \\
643 \\
643\end{array}$ \\
\hline $\begin{array}{l}H \\
H \\
H \\
H \\
H \\
H \\
H\end{array}$ & $\begin{array}{l}40: \\
41: \\
42: \\
43: \\
44: \\
45: \\
46:\end{array}$ & $\begin{array}{l}2.21 \\
2.21 \\
1.10 \\
1.04 \\
1.01 \\
1.61 \\
2.30\end{array}$ & $\begin{array}{l}7.5 \\
7.5 \\
7.5 \\
7.5 \\
7.5 \\
7.5 \\
7.5\end{array}$ & $\begin{array}{l}136.9 \\
135.6 \\
135.1 \\
140.6 \\
142.5 \\
142.1 \\
141.3\end{array}$ & $\begin{array}{l}58.1 \\
58.3 \\
59.4 \\
60.6 \\
56.0 \\
56.8 \\
55.6\end{array}$ & $\begin{array}{l}78.9 \\
77.3 \\
75.9 \\
80.0 \\
86.5 \\
85.3 \\
85.7\end{array}$ & $\begin{array}{l}\because: \\
\therefore: \\
\vdots: \\
\vdots: \\
\vdots: \\
\because: \\
::\end{array}$ & $\begin{array}{l}0.801 \\
0.802 \\
0.758 \\
0.744 \\
0.756 \\
0.803 \\
0.830\end{array}$ & $\begin{array}{l}\because: \\
\therefore: \\
\because: \\
\therefore: \\
\because: \\
\because: \\
\therefore:\end{array}$ & $\begin{array}{l}0.412 \\
0.408 \\
0.394 \\
0.401 \\
0.419 \\
0.429 \\
0.437\end{array}$ & $\begin{array}{l}: \\
: \\
: \\
:\end{array}$ & $\begin{array}{l}0.545 \\
0.542 \\
0.520 \\
0.523 \\
0.541 \\
0.560 \\
0.574\end{array}$ & $\begin{array}{l}\vdots \\
\vdots \\
\vdots \\
\vdots\end{array}$ & $\begin{array}{l}0.621: \\
0.619: \\
0.592: \\
0.591: \\
0.660: \\
0.634: \\
0.651:\end{array}$ & $\begin{array}{l}\vdots \\
\vdots \\
\vdots \\
:\end{array}$ & $\begin{array}{l}0.651: \\
0.648: \\
0.620: \\
0.617: \\
0.634: \\
0.662: \\
0.680:\end{array}$ & $\begin{array}{l}643 \\
643 \\
643 \\
643 \\
643 \\
643 \\
643\end{array}$ \\
\hline $\begin{array}{l}H \\
H \\
H \\
H \\
H\end{array}$ & $\begin{array}{l}63 \\
64 \\
65 \\
66 \\
67\end{array}$ & $\begin{array}{l}1.05 \\
1.65 \\
2.05 \\
2.53 \\
3.13\end{array}$ & $\begin{array}{l}21.4 \\
21.4 \\
21.4 \\
21.4 \\
21.4\end{array}$ & $\begin{array}{l}156.2 \\
144.1 \\
142.9 \\
136.2 \\
127.1\end{array}$ & $\begin{array}{l}72.1 \\
71.9 \\
71.0 \\
70.9 \\
70.6\end{array}$ & $\begin{array}{l}84.1 \\
72.3 \\
71.9 \\
65.3 \\
56.5\end{array}$ & $\begin{array}{l}:: \\
\because: \\
\therefore: \\
\therefore:\end{array}$ & $\begin{array}{l}0.756 \\
0.767 \\
0.802 \\
0.819 \\
0.837\end{array}$ & $\begin{array}{l}:: \\
\because: \\
:: \\
::\end{array}$ & $\begin{array}{l}0.413 \\
0.387 \\
0.394 \\
0.378 \\
0.352\end{array}$ & $\begin{array}{l}: \\
: \\
:\end{array}$ & $\begin{array}{l}0.537 \\
0.516 \\
0.530 \\
0.518 \\
0.496\end{array}$ & $\begin{array}{l}\vdots \\
\vdots \\
\vdots\end{array}$ & $\begin{array}{l}0.605: \\
0.590: \\
0.609: \\
0.603: \\
0.588:\end{array}$ & $:$ & $\begin{array}{l}0.631: \\
0.619: \\
0.640: \\
0.636: \\
0.625:\end{array}$ & $\begin{array}{l}643 \\
643 \\
643 \\
643 \\
643\end{array}$ \\
\hline $\begin{array}{l}\mathrm{H} \\
\mathrm{H} \\
\mathrm{H} \\
\mathrm{H} \\
\mathrm{H}\end{array}$ & $\begin{array}{l}92 \\
93 \\
94 \\
95 \\
96\end{array}$ & $\begin{array}{l}1.04 \\
1.64 \\
2.13 \\
2.55 \\
3.17\end{array}$ & $\begin{array}{l}21.4 \\
21.4 \\
21.4 \\
21.4 \\
21.4\end{array}$ & $\begin{array}{l}161.2 \\
151.6 \\
144.3 \\
137.8 \\
125.6\end{array}$ & $\begin{array}{l}70.3 \\
70.4 \\
69.4 \\
70.0 \\
70.3\end{array}$ & $\begin{array}{l}90 . \\
81 . \\
74 . \\
67 . \\
55 .\end{array}$ & $\begin{array}{l}:: \\
:: \\
:: \\
\vdots: \\
::\end{array}$ & $\begin{array}{l}0.723 \\
0.756 \\
0.772 \\
0.785 \\
0.791\end{array}$ & $\begin{array}{l}\because: \\
:: \\
\because: \\
\vdots: \\
::\end{array}$ & $\begin{array}{l}0.417 \\
0.406 \\
0.394 \\
0.378 \\
0.339\end{array}$ & : & $\begin{array}{l}0.531 \\
0.529 \\
0.523 \\
0.511 \\
0.476\end{array}$ & $\begin{array}{l}: \\
\vdots \\
:\end{array}$ & $\begin{array}{l}0.592: \\
0.598 \\
0.597: \\
0.590: \\
0.561:\end{array}$ & $\begin{array}{l}: \\
: \\
:\end{array}$ & $\begin{array}{l}0.615 \\
0.625: \\
0.625: \\
0.621: \\
0.596:\end{array}$ & $\begin{array}{l}643 \\
643 \\
643 \\
643 \\
643\end{array}$ \\
\hline $\begin{array}{l}H \\
H \\
H \\
H \\
H \\
H\end{array}$ & $\begin{array}{l}113 \\
118 \\
115 \\
116 \\
117 \\
118\end{array}$ & $\begin{array}{l}1.05 \\
1.68 \\
1.33 \\
2.09 \\
2.64 \\
3.06\end{array}$ & $\begin{array}{l}21.4 \\
21.4 \\
21.4 \\
21.0 \\
21.4 \\
21.4\end{array}$ & $\begin{array}{l}160.1 \\
149.5 \\
154.5 \\
145.5 \\
135.4 \\
128.1\end{array}$ & $\begin{array}{l}72.7 \\
72.7 \\
72.7 \\
71.8 \\
72.2 \\
72.5\end{array}$ & $\begin{array}{l}87.4 \\
76.8 \\
81.8 \\
73.8 \\
63.2 \\
55.6\end{array}$ & $\begin{array}{l}\vdots: \\
a: \\
:: \\
\vdots: \\
\vdots: \\
\therefore:\end{array}$ & $\begin{array}{l}0.728 \\
0.750 \\
0.733 \\
0.748 \\
0.759 \\
0.765\end{array}$ & $\begin{array}{l}:: \\
\vdots: \\
\vdots: \\
:: \\
\vdots: \\
i:\end{array}$ & $\begin{array}{l}0.409 \\
0.394 \\
0.401 \\
0.385 \\
0.359 \\
0.335\end{array}$ & $\begin{array}{c}\vdots \\
\vdots \\
\vdots \\
\vdots\end{array}$ & $\begin{array}{l}0.528 \\
0.518 \\
0.520 \\
0.510 \\
0.488 \\
0.467\end{array}$ & $\begin{array}{l}\vdots \\
\vdots \\
\vdots\end{array}$ & $\begin{array}{l}0.586: \\
0.588: \\
0.585: \\
0.581: \\
0.565: \\
0.548:\end{array}$ & $:$ & $\begin{array}{l}0.610: \\
0.615: \\
0.610: \\
0.608: \\
0.595: \\
0.581:\end{array}$ & $\begin{array}{ll}: & 643 \\
: & 643 \\
: & 643 \\
: & 643 \\
: & 643 \\
:= & 643\end{array}$ \\
\hline
\end{tabular}


Table 2d. Summary Data, Er, and EF - Unit I

SUMMAFY - UNIT I

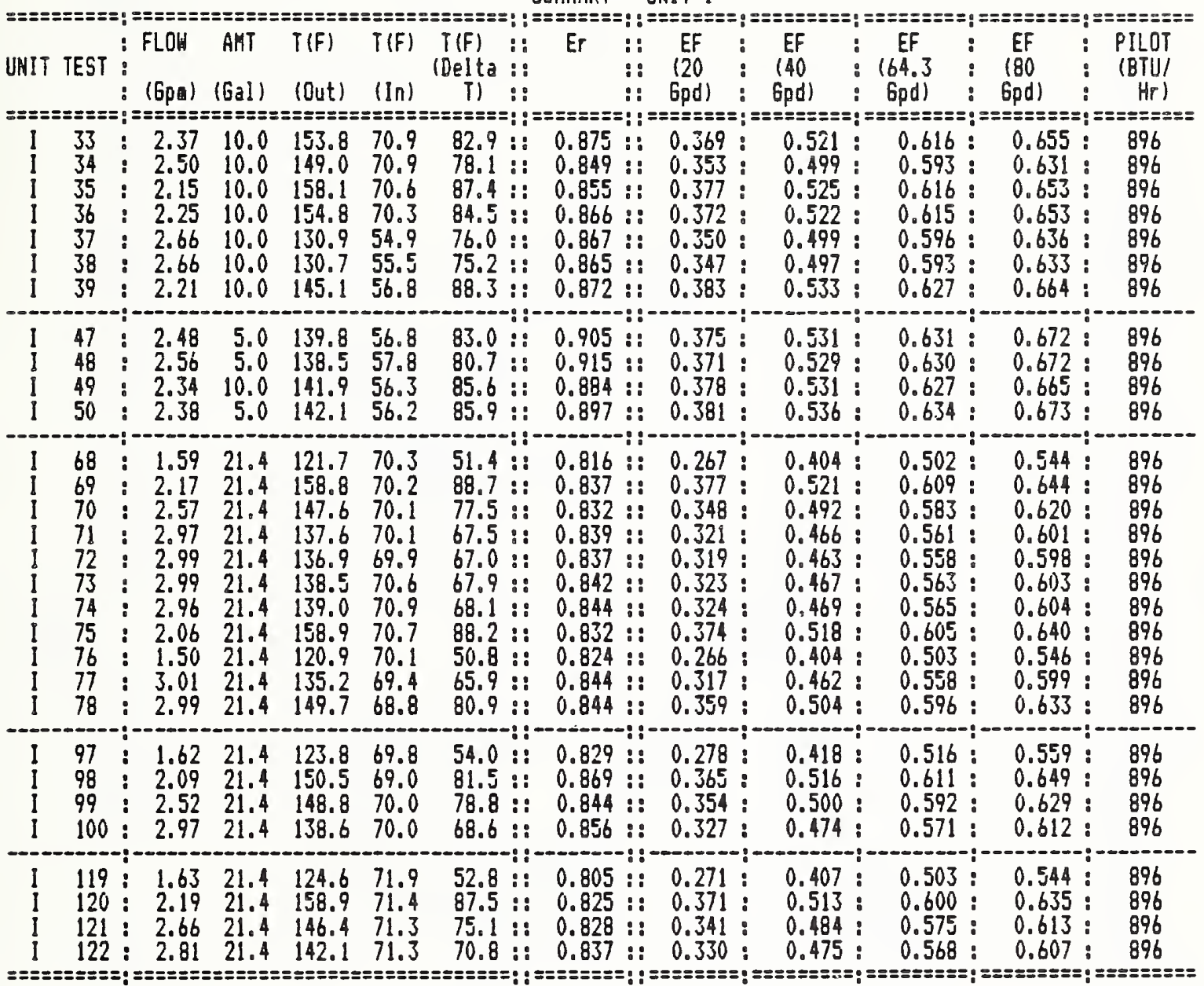




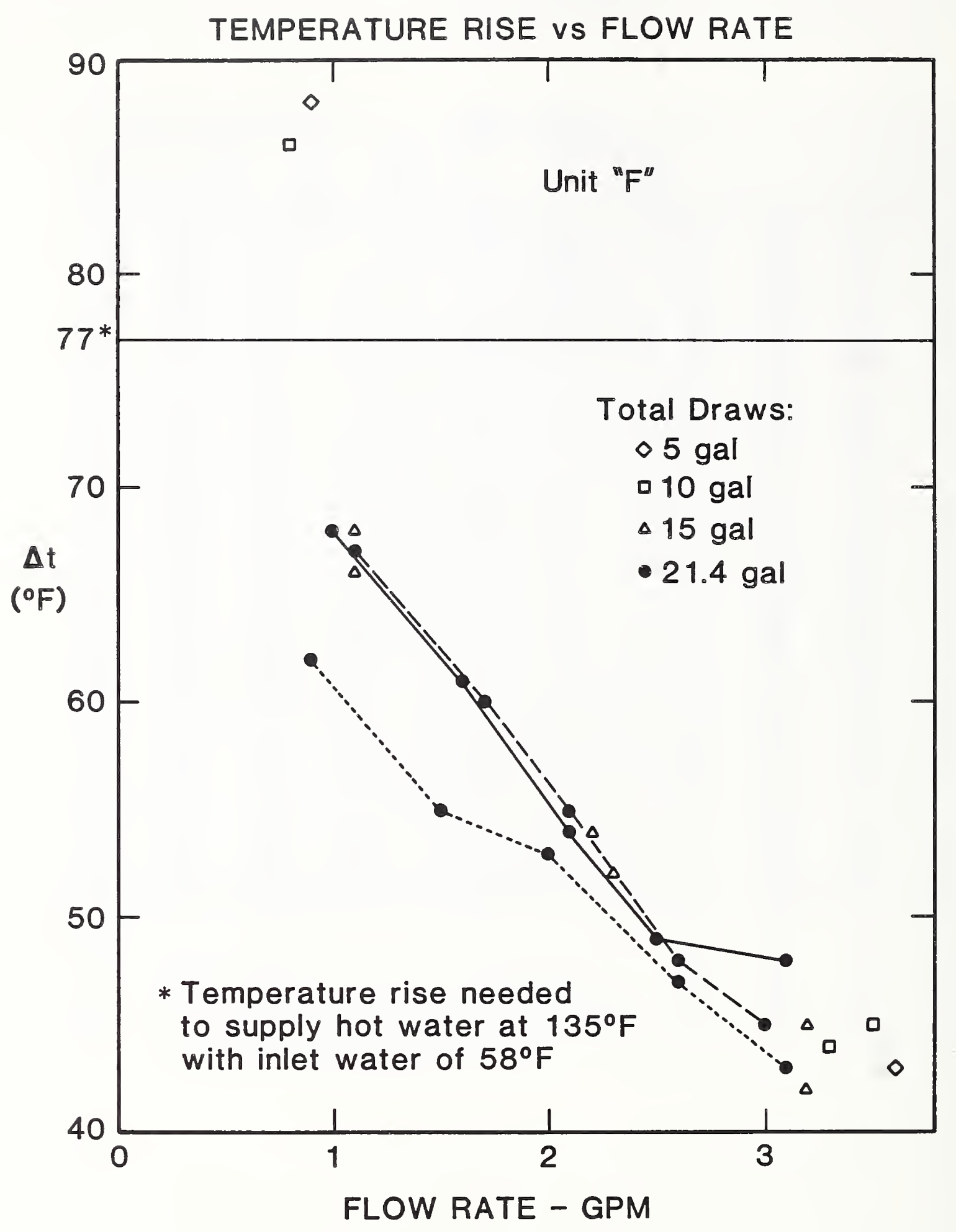

Figure 2。 Temperature Rise vs. Flow Rate - Unit F. 


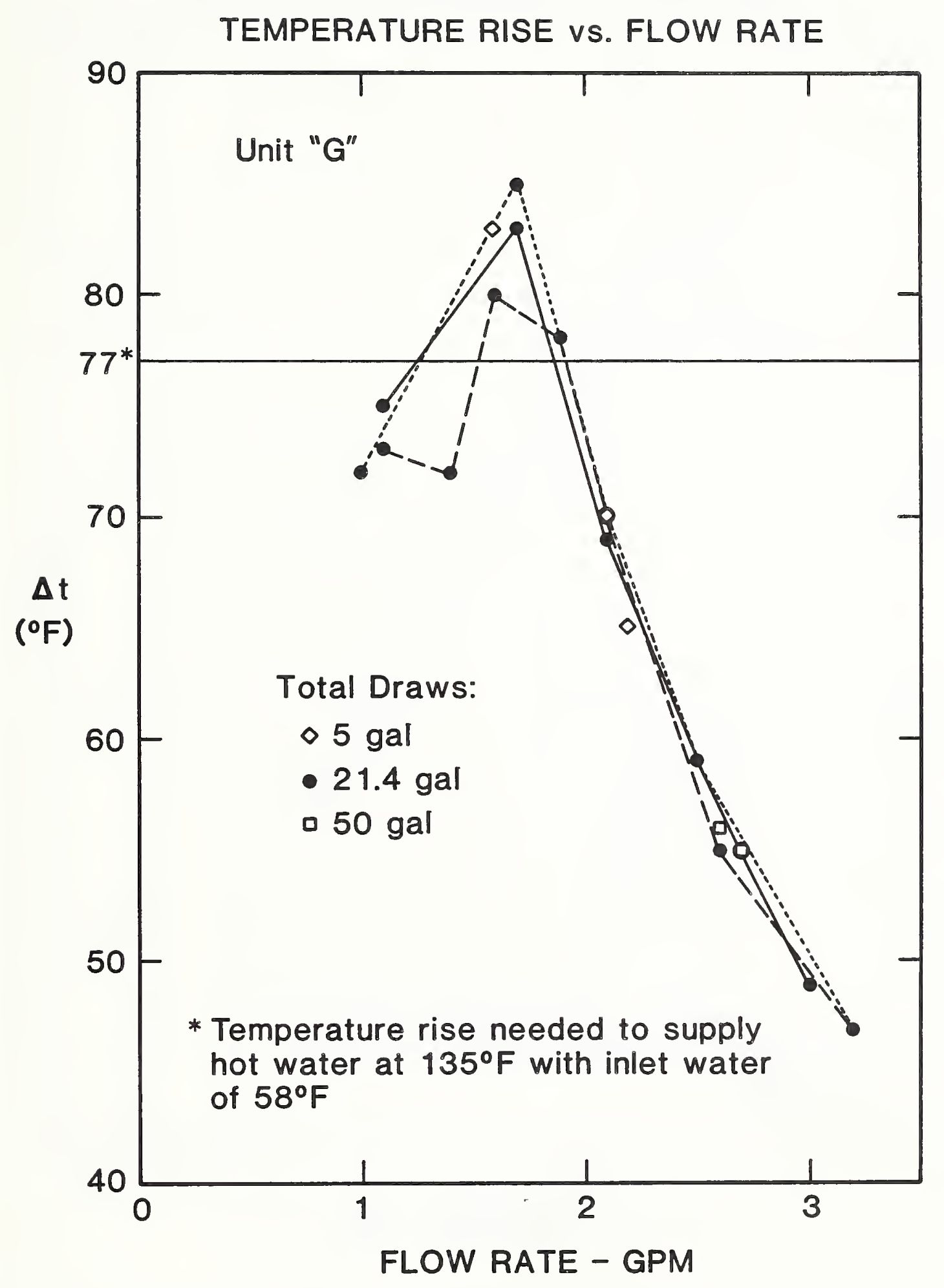

Figure 3. Temperature Rise vs. Flow Rate - Unit G. 
TEMPERATURE RISE vs. FLOW RATE

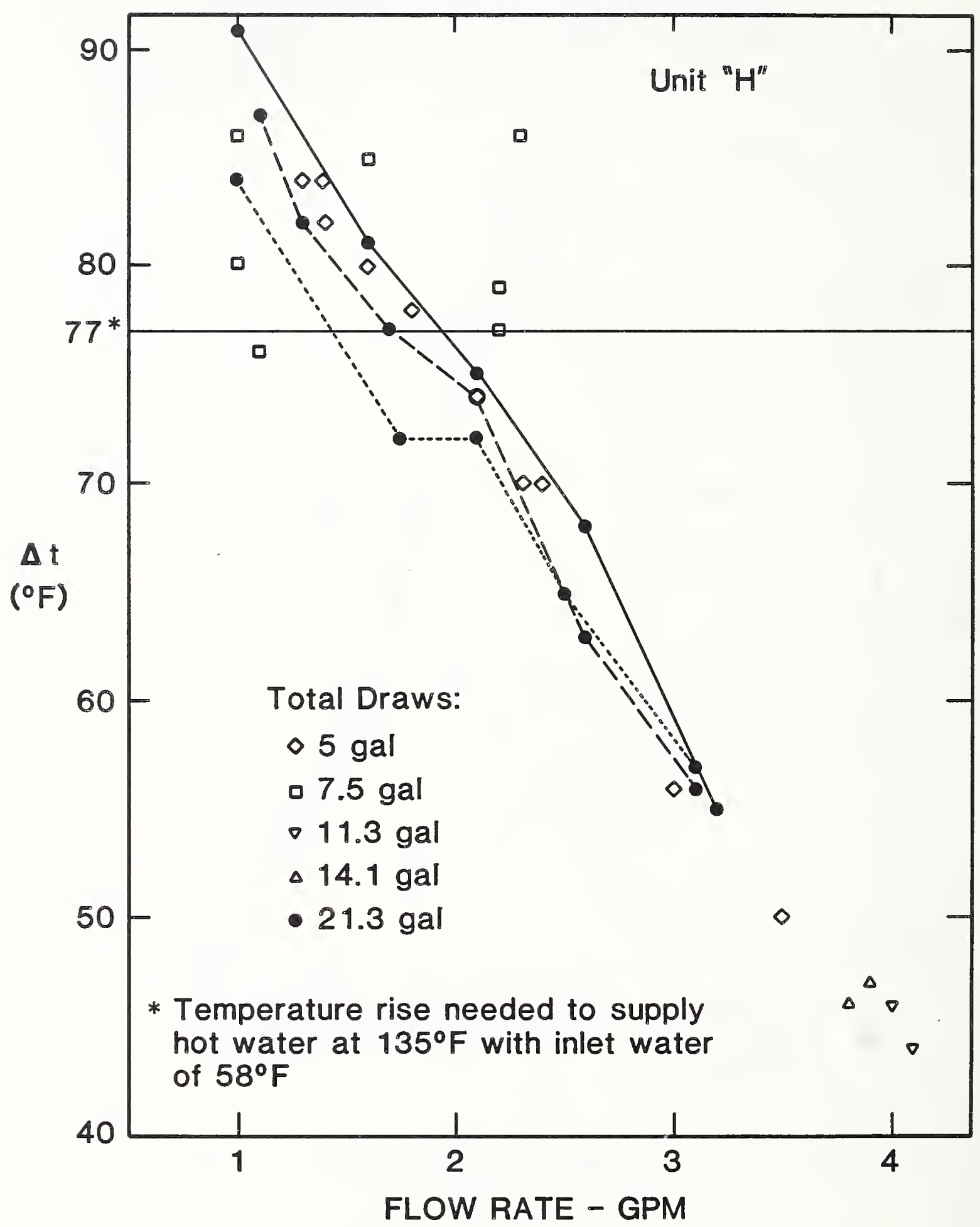

Figure 4. Temperature Rise vs. Flow Rate - Unit H. 


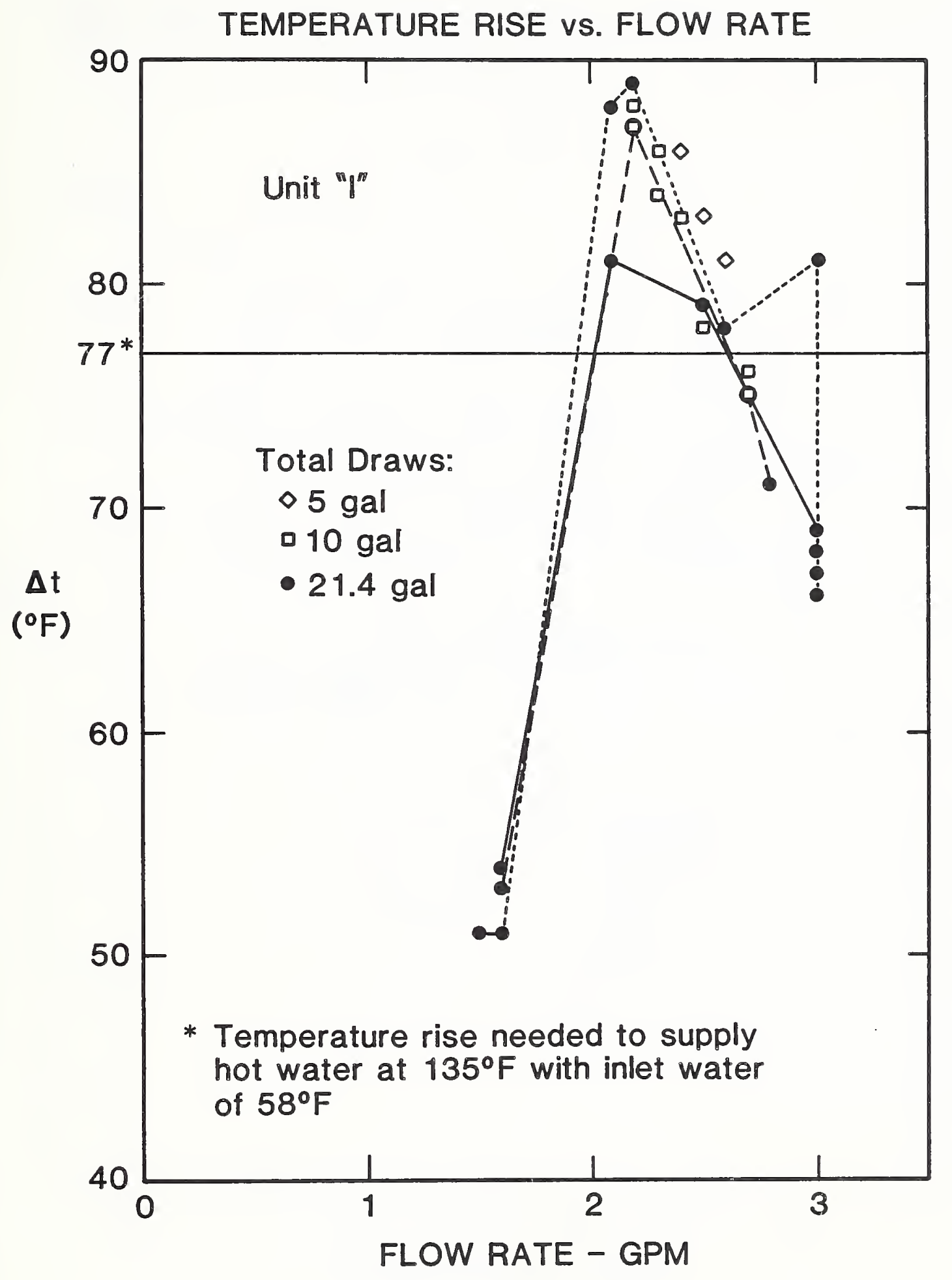

Figure 5. Temperature Rise vs. Flow Rate - Unit I. 


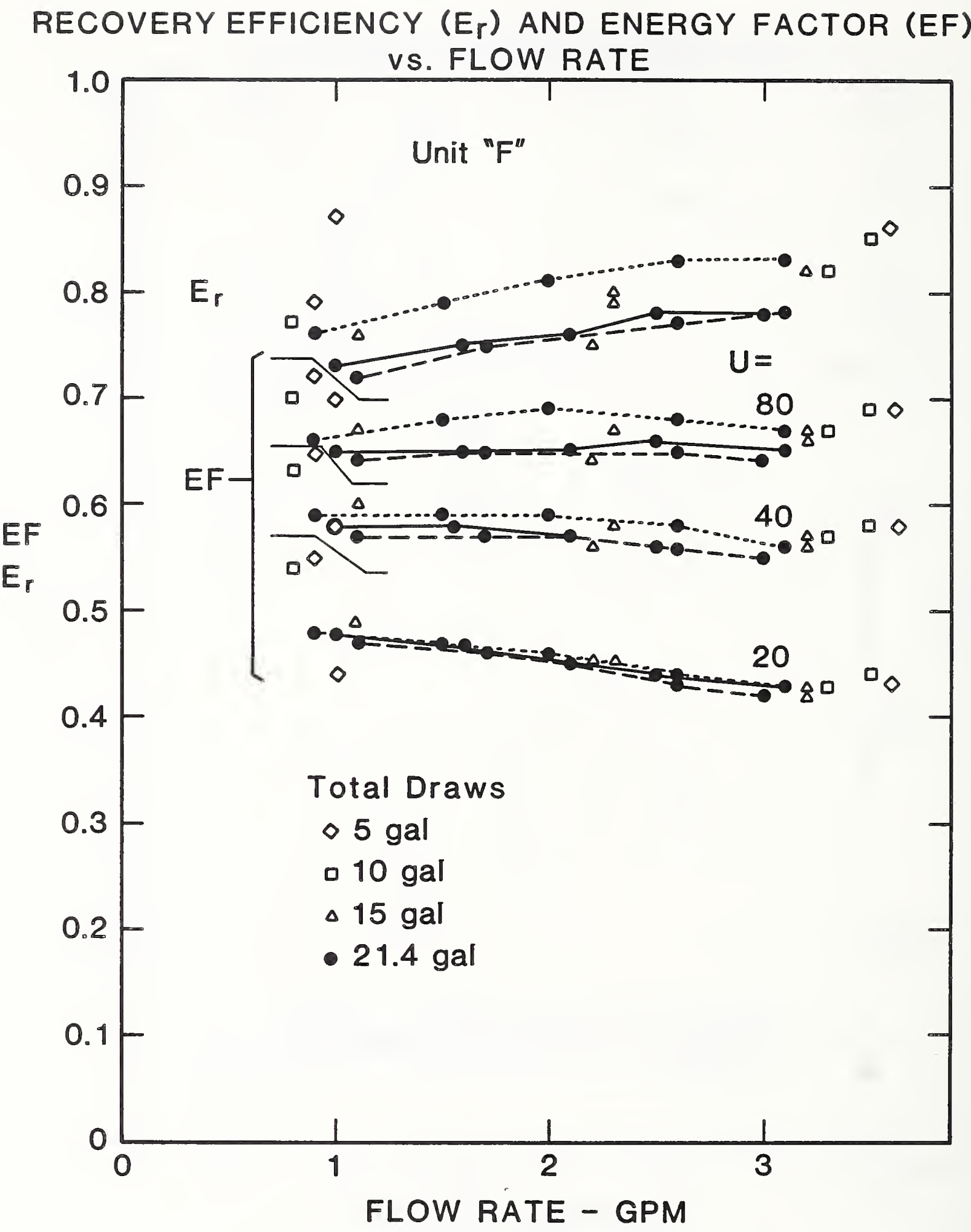

Figure 6. Recovery Efficiency (Er) and Energy Factor (EF) vs. Flow Rate - Unit F. 


\section{RECOVERY EFFICIENCY ( $E_{r}$ ) AND ENERGY FACTOR (EF)}

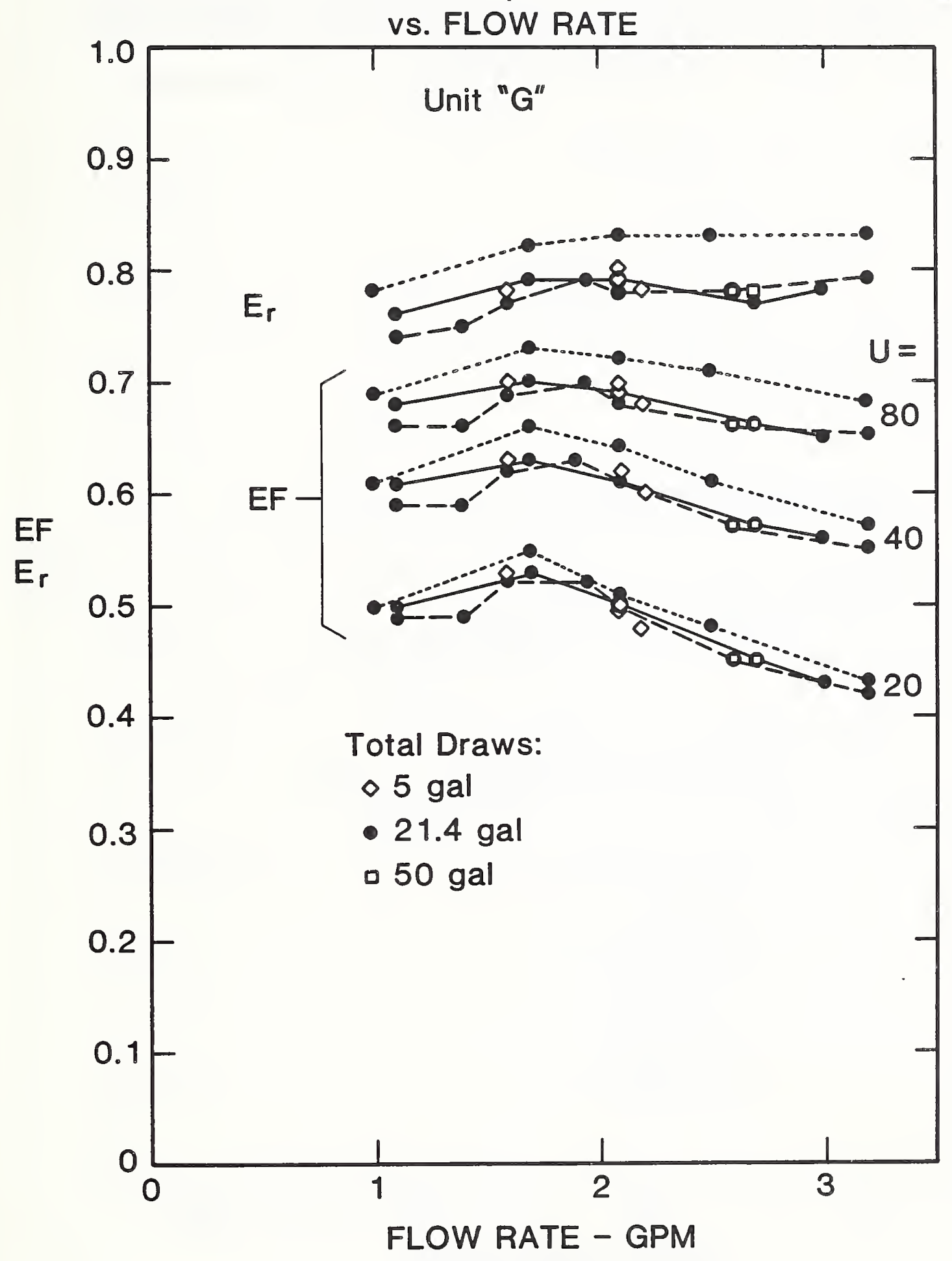

Figure 7. Recovery Efficiency (Er) and Energy Factor (EF) vs. Flow Rate - Unit G. 
RECOVERY EFFICIENCY $\left(E_{r}\right)$ AND ENERGY FACTOR (EF) vS. FLOW RATE

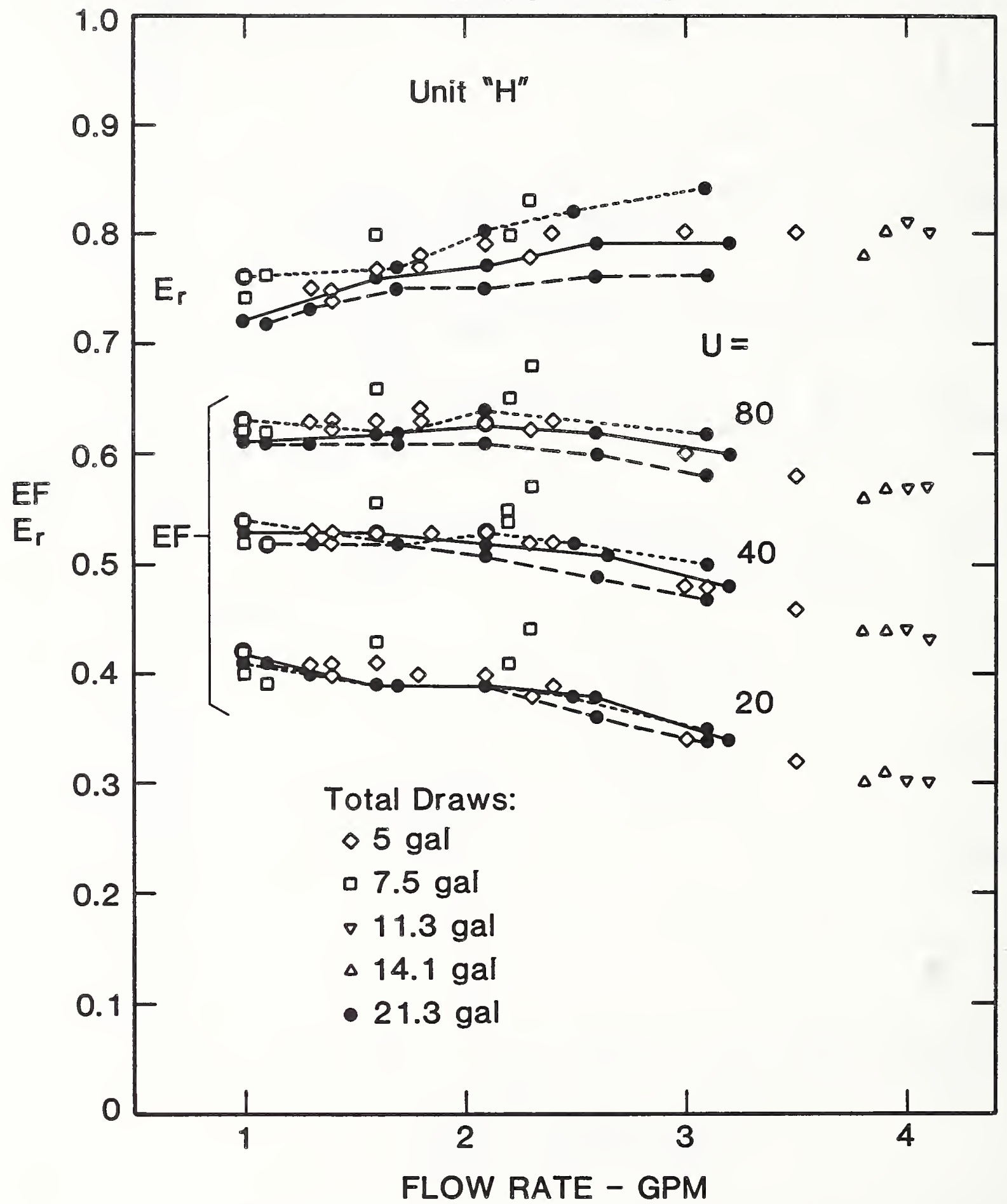

Figure 8. Recovery Efficiency (Er) and Energy Factor (EF) vs. Flow Rate - Unit H. 
RECOVERY EFFICIENCY (Er) AND ENERGY FACTOR (EF)

vs. FLOW RATE

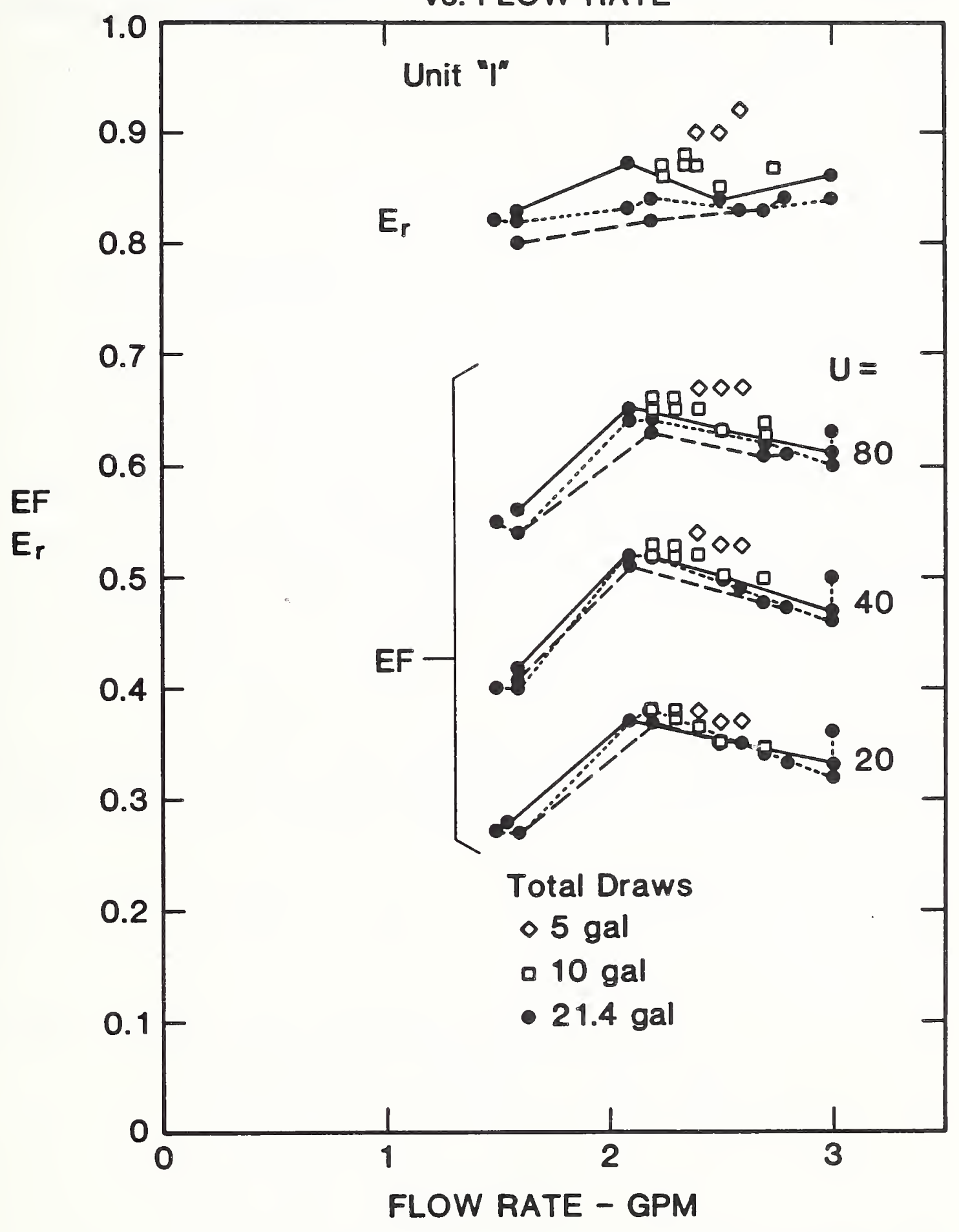

Figure 9. Recovery Efficiency (Er) and Energy Factor (EF) vs. Flow Rate - Unit I. 



\section{COMPUTATIONS AND FORMULAS USED}

In order to compute an energy factor to determine the annual cost of operation of an instantaneous gas-fired water heater, the following formulas are used in the order presented.

\subsection{Gas Correction Factor}

The correction factor, Cf, to determine the "standard" gas volume used was determined using equation (1) where "standard" conditions are at $60^{\circ} \mathrm{F}$ and 30.00 inches $\mathrm{Hg}$ (1016 millibars) atmospheric pressure. The partial pressure of the water vapor was determined from tables of vapor pressure of water at various temperatures, by entering the appropriate gas temperature. The other pressures were taken from appropriate instrument readings.

The correction factor, Cf, (dimensionless) to determine standard gas volume used during a gas water heater test and is defined as:

$\mathrm{Cf}=(17.64)(\mathrm{Pg}+\mathrm{Pa}-\mathrm{Pwv}) /(\mathrm{Tg}+460) \quad$ (dimensionless)

where: $\mathrm{Pg}$ is the gas pressure* (inches $\mathrm{Hg}$ );

$\mathrm{Pa}$ is the atmospheric pressure* (inches $\mathrm{Hg}$ );

Pwv is the water vapor pressure, partial (inches $\mathrm{Hg}$ );

$\mathrm{Tg}$ is the temperature of gas $\left({ }^{\circ} \mathrm{F}\right)$.

* NOTE: to convert inches of water to inches $\mathrm{Hg}$, multiply by 0.07343 ; to convert millibars to inches $\mathrm{Hg}$, multiply by 0.02953 . 


\subsection{Energy Used During a Test}

The energy used during a test was determined by equation (2) where the volume, Vol, of gas used during a test is corrected to standard conditions using $C f$ and is converted to $B$ tu using the higher heating value of the gas.

The energy used during a test is defined as:

$Q=(C f)(H)(V o l)$

(Btu)

where: Cf is the correction factor as defined in 1.0;

$\mathrm{H}$ is the higher heating value of gas used (Btu per SCF);

Vol is the volume of gas used during a test as measured by the gas meter (cubic feet).

\subsection{Mean Outlet Hot Water Temperature}

The mean value of the outlet hot water temperature, expressed in degrees F, was determined by equation (4) and is defined as:

Twout $=\mathrm{T} 1+\mathrm{T} 2+\ldots \mathrm{Tn} / \mathrm{n}$

where: $\quad T 1$ is the hot water temperature at the end of the first minute of the draw $\left({ }^{\circ} \mathrm{F}\right)$;

T2 is the hot water temperature at the end of the second minute of the draw $\left({ }^{\circ} \mathrm{F}\right)$;

$\mathrm{Tn}_{\mathrm{n}}$ is the hot water temperature at the start of the $\mathrm{nth}$ minute of the draw $\left({ }^{\circ} \mathrm{F}\right)$;

$n$ is the number of outlet hot water temperature measurements. 


\subsection{Mean Supply Water Temperature}

The mean value of the supply (cold) water temperature, expressed in degrees $F$, was determined by equation (5) and is defined as:

Twin $=\mathrm{Tl}+\mathrm{T} 2+\ldots \mathrm{Tn} / \mathrm{n}$

where: Tl is the cold water inlet temperature at the end of the first minute of the draw $\left({ }^{\circ} \mathrm{F}\right)$;

T2 is the cold water inlet temperature at the end of the second minute of the draw $\left({ }^{\circ} \mathrm{F}\right)$;

Tn is the cold water inlet temperature at the end of the nth minute of the draw $\left({ }^{\circ} \mathrm{F}\right)$;

$\mathrm{n}$ is the number of supply water temperature measurements.

\subsection{Recovery Efficiency}

The recovery efficiency during a test was determined by equation (3) and is defined as:

$\operatorname{Er}=(k)(V)(T l) /(Q)$

(dimensionless)

where: $k$ is the nominal specific heat of water during the temperature ranges used $\left(8.25 \mathrm{Btu} / \mathrm{gallon}^{\circ} \mathrm{F}\right)$;

$V$ is the volume of the water draw during the test (U.S. gallons);

T1 is the mean temperature rise $\left({ }^{\circ} \mathrm{F}\right)$ of the hot water drawn during test and is equal to (Twout-Twin);

(Twout) is defined in 3.0 ;

(Twin) is defined in 4.0 ;

$Q$ is defined in 2.0 . 


\subsection{Daily Water Heating Energy Consumption}

The daily water heating energy consumption, expressed in Btu per day and using an established daily hot water usage of 64.3 gallons was determined by equation (6) and is defined as:

$C_{w h}=(k)(U)(T I) /\left(E_{r}\right)$

(Btu/day)

where: $\mathrm{k}, \mathrm{Tl}$ and $\mathrm{Er}$ are defined in 5.0;

$\mathrm{U}$ is the established daily hot water usage, 64.3 gallons.

NOTE: When the value of $U$ differs from 64.3 gallons, the actual measured gallons is used for the computations.

The actual hot water temperature rise (TI) is used instead of an assumed or fixed value because the power input rate for most instantaneous gas-fired water heaters is variable. In addition, the actual temperature rise of the water is variable and it may differ significantly from any fixed or assumed value.

\subsection{The Flow Rate During a Draw}

The flow rate of hot water during a draw was determined by equation (7) by weighing the water from a draw and timing the draw. The flow rate is defined as:

$F_{r}=W w /((T d)(8.25))$

(ga1/min)

where: Ww is the weight of the water during the draw in pounds;

Td is the duration of the draw in minutes; 
8.25 is a constant to convert pounds of water to gallons of water.

\subsection{Power (Firing Rate) Determination}

The average power, in Btu/hour, input for a given test was determined by equation ( 8 ) and is defined as:

$P=(60 \mathrm{~min} /$ hour $)(\mathrm{Q}) /(\mathrm{Tb}) \quad(\mathrm{Btu} /$ hour $)$

where: $Q$ is defined in 2.0;

$\mathrm{Tb}$ is the duration of the burner on time in minutes;

60 is a constant to convert minutes to hours.

\subsection{Daily Hot Water Energy Consumption}

The daily hot water energy consumption was determined by equation (9) and is defined as:

$C_{c}=(k)(U)(T 1)$

(Btu/day)

where: $\quad k$ and $\mathrm{T} 1$ are defined in 5.0 ;

$\mathrm{U}$ is defined in 6.0 .

\subsection{Pilet Light Energy Consumption Rate}

The pilot light energy consumption rate was measured for each unit. These tests were conducted by measuring the volume of gas used by the pilot light (Vol), correcting to a standard conditions by equation ( 1 ) in 1.0 by determining the value of $\mathrm{Cf}$ and measuring the duration of the 
pilot light energy consumption rate was then determined by equation (10) and is defined as:

$\begin{array}{ll}\operatorname{Pr}=\left(V_{0 l}\right)(C f)(H) /\left(T_{P}\right) & (B t u / h o u r)\end{array}$

where: Vol is the cubic feet of gas measured by the gas meter during the pilot light test expressed in cubic feet;

Cf is defined in 1.0 ;

$\mathrm{H}$ is defined in 2.0 ;

$T_{p}$ is the duration of the pilot light test in hours (nominally 22 hours).

\subsection{Average Daily Energy Consumption}

The average daily energy consumption was determined by equation (11) and is defined as:

$\begin{array}{cl}C y \\ C\end{array} C_{w h}+\left(P_{r}\right)\left(24-(U) /\left((60)\left(F_{r}\right)\right)\right) \quad(B t u / d a y)$

where: Cwh and $U$ are defined in 6.0 ;

$\operatorname{Pr}$ is defined in 10.0 ;

Fr is defined in 7.0 ;

60 is a constant to convert minutes to hours and 24 is the hours per day.

\subsection{Energy Factor}

The energy factor was determined by equation (12) and is defined as:

$$
\mathrm{EF}=(\mathrm{Cc}) /(\mathrm{Cy}) \quad \text { (dimensionless) }
$$


where: $\quad(\mathrm{Cc})$ is defined in 9.0;

(Cy) is defined in 11.0 . 

Appendix B

UNITS CONVERSION TABLE: SI/INCH-POUND/SI

\begin{tabular}{|c|c|c|}
\hline TO CONVERT & MULTIPLY BY & TO OBTAIN \\
\hline $\begin{array}{l}\text { gpm } \\
\text { (Gallons/minute) }\end{array}$ & 0.06309 & $\begin{array}{l}\mathrm{L} / \mathrm{s} \\
\text { (Liters/second) }\end{array}$ \\
\hline $\begin{array}{l}\mathrm{L} / \mathrm{s} \\
\text { (Liters/sec ond) }\end{array}$ & 15.85 & $\begin{array}{l}\text { gpm } \\
\text { (Gallons/minute) }\end{array}$ \\
\hline $\begin{array}{l}g \\
\text { (Ga1lons) }\end{array}$ & 3.785 & $\begin{array}{l}\text { L } \\
\text { (Liters) }\end{array}$ \\
\hline $\begin{array}{l}\mathrm{L} \\
\text { (Liters) }\end{array}$ & 0.2642 & $\stackrel{g}{\text { (Ga1lons) }}$ \\
\hline $\begin{array}{l}\text { in } \\
\text { (Inches) }\end{array}$ & 2.54 & $\begin{array}{l}\text { cm } \\
\text { (Centimeters) }\end{array}$ \\
\hline $\begin{array}{l}\text { cm } \\
\text { (Centimeters) }\end{array}$ & 0.3937 & $\begin{array}{l}\text { in } \\
\text { (Inches) }\end{array}$ \\
\hline $\begin{array}{l}\text { ft } \\
\text { (Feet) }\end{array}$ & 0.3048 & (Meters) \\
\hline (Meters) & 3.281 & $\begin{array}{l}\mathrm{ft} \\
\text { (Feet) }\end{array}$ \\
\hline $\begin{array}{l}\text { BTU } \\
\text { (British Thermal Units) }\end{array}$ & 1.055 & $\begin{array}{l}\mathrm{kJ} \\
\text { (Kilojoules) }\end{array}$ \\
\hline $\begin{array}{l}\mathrm{kJ} \\
\text { (Kilojoules) }\end{array}$ & 0.9479 & $\begin{array}{l}\text { BTU } \\
\text { (British Thermal Units) }\end{array}$ \\
\hline
\end{tabular}

TEMPERATURE $(T)$, CONVERSION EQUATIONS:

For Temperature Use:

$$
\begin{array}{ll}
{ }^{\circ} \mathrm{F} \text { to }{ }^{\circ} \mathrm{C}: & {\left[(\mathrm{T}){ }^{\circ} \mathrm{F}-32{ }^{\circ} \mathrm{F}\right](5 / 9)=(\mathrm{T}){ }^{\circ} \mathrm{C}} \\
{ }^{\circ} \mathrm{C} \text { to }{ }^{\circ} \mathrm{F}: & {\left[(\mathrm{T}){ }^{\circ} \mathrm{C}(9 / 5)+32{ }^{\circ} \mathrm{F}=(\mathrm{T}){ }^{\circ} \mathrm{F}\right.}
\end{array}
$$

FOR TEMPERATURE DIFFERENTIALS OR TOLERANCES USE:

$$
\begin{aligned}
& { }^{\circ} \mathrm{F} \text { to }{ }^{\circ} \mathrm{C}:(\mathrm{T}){ }^{\circ} \mathrm{F}(5 / 9)=(\mathrm{T}){ }^{\circ} \mathrm{C} \\
& { }^{\circ} \mathrm{C} \text { to }{ }^{\circ} \mathrm{F}:(\mathrm{T}){ }^{\circ} \mathrm{C}(9 / 5)=(\mathrm{T}){ }^{\circ} \mathrm{F}
\end{aligned}
$$


